\title{
Choosing Environmental Instruments in a Transnational Context
}

\author{
David M. Driesen*
}

A transnational legal process approach enhances understanding of instrument choice in international environmental law. International allowance trading depends upon international transactions and therefore requires detailed international legal rules. Since enacting these rules generally requires unanimous consent, agreement to a well-designed international trading program will prove difficult. Because key countries may either oppose trading as inequitable or not agree to good design criteria, international allowance trading may discourage effective participation in international agreements. An approach that relies upon national compliance using nationally chosen methods merits consideration as an alternative to international selection of environmental instruments.

CONTENTS

Introduction ............................................................. 2

I. Background on the Instrument Choice Debate and Transnational Legal Process ....................................5

A. Transnational Legal Process ................................ 5

B. The Instrument Choice Debate ............................ 7

II. Equity and Cost-Benefit Calculations as Predictors of Assent to Treaties ............................................... 11

III. The Choice Between Transnational Pluralism and International Coordination of Instrument Choice and Design Details

A. A Transnational Legal Process Model of Global Environmental Law. 15

B. The Pluralism Option.................................... 18

Copyright () 2000 by The Regents of the University of California

* Associate Professor, Syracuse University College of Law. J.D., Yale Law School. I would like to thank Professors Edith Brown Weiss, Lisa Heinzerling, and Samuel Donnelly for very helpful comments on earlier versions of this Article. I, of course, take responsibility for any errors in the final text. 


\section{International Allowance Trading's Increased}

Demands for International Coordination .................23

1. Abstract Agreement About Instrument Choice......23

2. International Coordination of Design Details ........25

a. Non-Capped Programs ................................28

b. Capped Programs................................... 30

c. Legal Assumptions in Compliance

Discussions

IV. Comparative Analysis Using the Transnational

Approach

A. Whose Cost Counts? Comparing Taxes and

Allowance Trading

B. Comparing Trading and Performance Standards .......40

C. The Missing Link: Participation Cost and Domestic Legal Process.............................................. 44

\section{INTRODUCTION}

Developing countries have generally opposed international adoption of allowance trading ${ }^{1}$ as an instrument to address global environmental problems. ${ }^{2}$ International allowance trading allows a country to forego adopting environmental measures at home to comply with international legal obligations to the extent it finances compensating environmental improvements outside its territory. This opposition to allowance trading suggests that insistence on international adoption of allowance trading may discourage much needed effective developing country participation in international environmental agreements.

Almost a decade of effort to create an international trading program in the climate change context ${ }^{3}$ has failed to produce

1. See J.H. Dales, POllution Property \& PRices 92-100 (1968) (explaining allowance trading).

2. See Joyeeta Gupta, The Climate Change Convention and Developing Countries: From Conflict to Consensus 122-23 (1997); Deborah E. Cooper, The Kyoto Protocol and China: Global Warming's Sleeping Giant, 11 GEO. INT'L ENVTL. L. REV. 401, 422 (1999) (noting that developing countries strongly opposed emissions trading at Kyoto, and that "China's opposition was so strong that Chairman Raul Estrada thought it might "blow apart' the entire negotiations."); Soma Basu, India Sticks to Stand on Global Climate Change, THE HINDU (India) (Mar. 11, 1999), available at <http://www.indiaserver.com/thehindu/1999ft/03/11/stories/ $0211000 \mathrm{f} . \mathrm{html}>$ [hereinafter India] (emissions trading is "essentially a U.S. proposal, which sharpens and deepens the north-south divide").

3. See Jonathan Green \& Philippe Sands, Establishing an International System for Trading Pollution Rights, 15 Int'l Env't Rep. (BNA) 80, 82-83 (Feb. 12, 1992) (discussing early efforts to make trading part of the regime). 
agreement on a workable set of ground rules. ${ }^{4}$ And no international regime has an active allowance trading program in place. ${ }^{5}$ Scholars impressed by the conventional view of allowance trading's advantages ${ }^{6}$ have ignored this failure to agree upon detailed rules ${ }^{7}$ and have treated developing country opposition as either a form of myopia ${ }^{8}$ or rent seeking. ${ }^{9}$

This Article, however, takes the failure to agree upon ground rules and the views of foreign countries more seriously and argues that we need to reexamine the theory of environmental instrument choice in the international context. This Article argues that transnational legal process insights would greatly enrich our understanding of instrument choice to combat global environmental problems. ${ }^{10} \mathrm{~A}$ theory of transnational legal

4. See Report of the Conference of the Parties on its Fourth Session. Held at Buenos Aires from 2 to 14 November 1998, 4th Sess., at 22-23, U.N. Doc. FCCC/CP/1998/16/Add.1 (1999) [hereinafter Buenos Aires Report] (noting that, after failing to agree upon ground rules for emissions trading, the parties agreed to a work program for subsidiary bodies). See generally Laura B. Campbell \& Chad W. Carpenter, The Kyoto Protocol on Climate Change: Implementing the Buenos Aires Action Plan, 22 Int'l Env't Rep. (BNA) 695 (Aug. 18, 1999).

5. The Kyoto Protocol to the United Nations Framework Convention on Climate Change has provisions that authorize trading, but the failure to agree upon ground rules has slowed trading. See David $M$. Driesen, Free Lunch or Cheap Fix?: The Emissions Trading Idea and the Climate Change Convention, 26 B.C. ENVTL. AFF. L. REv. 1, 27-35 (1998) [hereinafter Driesen. Free Lunch] [describing the relevant provisions). Some parties have undertaken projects designed to demonstrate the feasibility of trading under the climate change convention, but without selling credits earned from the projects to parties with control obligations. See id. at 29-30, 84; see also Axel P. Gosseries. The Legal Architecture of Joint Implementation: What Do We Learn from the Pilot Phase?, 7 N.Y.U. ENVTL. L.J. 49 (1999). The Montreal Protocol on Ozone Depleting Substances authorized limited trading, but little actual trading resulted. See Driesen, Free Lunch, supra, at 87 n.430.

6. For the conventional view, see generally Bruce A. Ackerman \& Richard B. Stewart, Reforming Environmental Law: The Democratic Case for Market Incentives, 13 Colum. J. ENvTL. L. 171 (1988); Daniel J. Dudek \& John Palmisano, Emissions Trading: Why Is This Thoroughbred Hobbled?, 13 Colum. J. ENVTL. L. 217 (1988); Robert W. Hahn \& Gordon L. Hester, Where Did All the Markets Go? An Analysis of EPA's Emissions Trading Program, 6 YALE J. ON REG. 109 (1989); Robert W. Hahn \& Robert N. Stavins, Incentive-Based Regulation: A New Era for an Old Idea?, 18 ECOLOGY L.Q. 1 (1991).

7. See, e.g., Jonathan Baert Wiener, Global Environmental Regulation: Instrument Choice in Legal Context, 108 YALE L.J. 677, 713 (1999) [hereinafter, Wiener. Global Environmental Regulation) (mentioning but attributing no significance to failure to agree on ground rules).

8. See, e.g., id. at 720-25 (arguing that fairness concerns about trading are misplaced).

9. See, e.g., Jonathan Baert Wiener, On the Political Economy of Global Environmental Regulation, 87 GEO. L.J. 749, 775-88 (1999) (hereinafter Wiener. Political Economyl (suggesting various elaborate theories of rent seeking and other disingenuous motives).

10. See generally LyNne M. JuRgielewicz, GLobal Environmental Change and 
process goes beyond analysis of the process of countries negotiating international treaties. It examines issues of how national legal and political processes contribute to the formulation and implementation of international legal rules. This includes consideration of transnational relationships and transactions among sub-national groups and individuals in different countries. A transnational approach strengthens understanding of instrument choice because it focuses more attention on the role of equity considerations and national implementation of international environmental agreements.

This richer view does not inexorably create a general conclusion about which instrument an international regime should use. Instead, it leads to a fuller appreciation of the questions that require further analysis, including whether parties to international environmental treaties should leave the choice of instruments to meet international environmental obligations to national governments or make the choice collectively in international negotiations. This question may be the most important legal process question facing global environmental governance, but it has received very little attention because most scholars writing about instrument choice rely upon an economic analysis that often treats the international legal process as irrelevant.

Professor Jonathan Wiener, however, has made the legal process central to his analysis of instrument choice in the international context. But he focuses little attention upon transnational legal process. This Article analyzes many of Professor Wiener's arguments to show how a transnational approach changes even an analysis of instrument choice that takes part of the process of international legal development into account.

Part I introduces the instruments, some of the ideas surrounding them, and the idea of transnational legal process. In particular, it places emphasis upon Professor Wiener's recent argument that allowance trading will encourage more participation in international environmental agreements than competing instruments. ${ }^{11}$ Attention to transnational legal process

INTERNATIONAL LAW: PROSPECTS FOR PROGRESS IN THE LEGAL ORder (1996): Harold Hongju Koh, Transnational Legal Process, 75 NEB. L. REv. 181 (1996) Thereinafter Koh, Transnational; Harold Hongju Koh, The 1998 Frankel Lecture: Bringing International Law Home, 35 Hous. L. REV. 623 (1998) [hereinafter Koh, Home]; Harold Hongju Koh, Why Do Nations Obey International Law?, 106 YALE L.J. 2599 (1997) [hereinafter Koh, Obey].

11. See generally Wiener, Global Environmental Regulation, supra note 7. 
casts doubt on this argument.

Part II argues that analysts wishing to construct theories about how instrument choice might affect participation must take countries' actual perceptions of equity seriously. These perceptions may help explain why many countries reject allowance trading. This Part questions the idea that analyses of national cost-benefit calculations under competing instruments can adequately explain instrument choice's affect upon participation decisions.

Part III explains how greater attention to transnational legal process raises important questions about instrument choice. International instrument choice may reduce nations' opportunities to tailor their own instrument choices to national circumstances. International allowance trading creates unique compliance difficulties that present barriers to effective international environmental law because their solution requires more detailed international agreements under voting rules requiring the voluntary assent of participating countries.

Part IV applies the transnational approach to comparative instrument choice. This analysis casts doubt on the argument that allowance trading enjoys superiority over pollution taxes and traditional regulation as a global environmental regulatory instrument.

This Article concludes that a transnational legal process perspective clarifies instrument choice, calling attention to significant potential problems with instruments dependent upon effective international coordination of design details. It also reaches some general conclusions about the relationship between economics and legal analysis.

BACKGROUND ON THE INSTRUMENT CHOICE DEBATE AND TRANSNATIONAL LEGAL PROCESS

This Part introduces the idea of transnational legal process, and then provides some background on the instrument choice debate. This will establish a foundation for the argument that an understanding of transnational legal process should inform instrument choice.

\section{A. Transnational Legal Process}

Professor Harold Koh has promoted a transnational legal 
process model of international law. ${ }^{12}$ Professor Koh rejects as simplistic a rationalistic model of international law. He argues that the assumption that states act rationally in deciding whether to cooperate with other states is "demonstrably false" in the environmental area and other areas. ${ }^{13}$ Most serious students of international environmental law agree with Koh's view that multiple factors influence national decisions to participate in international environmental agreements and emphasize the role countries' equitable perceptions (along with other factors) play in participation decisions. ${ }^{14}$

The transnational legal process theory seeks to explain why nations obey international law. ${ }^{15}$ It finds insufficient the rationalist premise that nations only agree to measures reflecting positive cost-benefit calculations and then comply with agreements regularly because it is in their interest to do so. ${ }^{16}$ It seeks to understand how norms become internalized so that they influence national conduct. ${ }^{17}$

Transnational legal process theory emphasizes the role that national implementation and individual action play in carrying out international agreements. ${ }^{18}$ In the environmental area, this emphasis upon national implementation is crucial because international environmental law generates no progress unless international agreements establish a legal process that ultimately produces private changes of conduct to protect the environment. ${ }^{19}$

12. See, e.g., Koh, Home, supra note 10, at 626-27, 672-81; Koh, Obey, supra note 10, at 2648-59; Koh, Transnational, supra note 10, at 183-207.

13. Koh, Transnational, supra note 10, at 192-93.

14. See, e.g.. Harold K. Jacobson \& Edith Brown Weiss, Assessing the Record and Designing Strategies to Engage Countries, in ENGAGING COUNTRIES: STRENGTHENING COMPLIANCE WITH INTERNATIONAL ENVIRONMENTAL ACCORDS 523 (Edith Brown Weiss \& Harold K. Jacobson eds., 1998) [hereinafter ENGAGING CoUNTRIESl.

15. See Koh, Obey, supra note 10, at 2602-03.

16. See id. at 2621-22 (discussing rationalist assumptions in Henkin's work and pointing out that the work fails to explore how international law reshapes domestic laws, bureaucracies, and decisionmakers); Koh. Transnational, supra note 10, at 19293 (disagreeing with the rationalist assumption); Edith Brown Weiss \& Harold $\mathrm{K}$. Jacobson, A Framework for Analysis, in ENGAGING COUNTRIEs, supra note 14, at 2 (stating that rationalist premises are inadequate because many reasons other than cost-benefit calculations affect countries' perceptions of their self-interest).

17. See Koh, Home, supra note 10, at 642-73.

18. See David A. Wirth, Reexamining Decision-Making Processes in International Environmental Law, 79 lOWA L. REV. 769, 778-802 (1994) (explaining how increased public involvement might aid implementation of international environmental agreements).

19. Accord THE IMPLEMENTATION AND EFFECTIVENESS OF INTERNATIONAL ENVIRONMENTAL COMmITMENTS: THEORY AND PRACTICE 4 (David G. Victor et al. eds., 1998) [hereinafter EFFECTIVENESS]; David A. Wirth, The International Trade Regime 
One might think of a transnational model of international legal process as a vertical model and contrast it with a horizontal model. ${ }^{20}$ The horizontal model emphasizes the relations between states. ${ }^{21}$ The vertical model emphasizes what happens within states and between various non-state actors. ${ }^{22}$

Instrument choice scholars have paid little attention to the implications of the transnational legal process idea. ${ }^{23}$ But the rejection of cost-benefit based rationalist assumptions and the emphasis on equity and implementation have important implications for instrument choice.

\section{B. The Instrument Choice Debate}

Regulators may choose from a variety of instruments to address environmental problems. Regulators may, for example, use traditional regulations. ${ }^{24}$ These include performance standards, which typically require a quantitative change of some kind, and the less frequently employed command and control regulations that require use of a particular abatement technique. ${ }^{25}$

Allowance trading offers a variant upon a performance standard. Regulators establish quantitative limits for pollution, but then authorize trades. ${ }^{26}$ This means that a polluter can

and the Municipal Law of Federal States: How Close a Fit?, 49 WASH. \& LEE L. REV. 1389,1397 (1992) (arguing that international environmental obligations require affirmative government actions).

20. See Abram Chayes \& Antonia Handler Chayes, THe New SOVEREIGNTy 1-3 (1995) (arguing that modern times have witnessed a move to horizontal regulation via treaty regimes); Koh, Home, supra note 10, at 626-27 (arguing that traditional international legal theories focus on "horizontal jawboning").

21. See Koh, Home, supra note 10, at 635 (stating that the traditional focus of international legal process theorists has been on the horizontal process that occurs among nation-states interacting within global treaty regimesl.

22. See generally id. at $646-55$ (discussing various actors' role in 'norm internalization").

23. I have used the model to develop a concept of accountability in evaluating allowance trading. See Driesen, Free Lunch, supra note 5, at 21-23, 56-57. To my knowledge, no other commentator has explicitly applied a transnational legal process model to instrument choice questions. $C f$. Wiener, Global Environmental Regulation, supra note 7 (using a rationalistic model based primarily on a horizontal analysis).

24. See David M. Driesen, Is Emissions Trading an Economic Incentive Program?: Replacing the Command and Control/Economic Incentive Dichotomy, 55 WASH. \& LEE L. REv. 289, 295-311 (1998) [hereinafter Driesen, Emissions Trading] (explaining the weaknesses and strengths of traditional regulation); Sidney A. Shapiro \& Thomas $O$. McGarity. Not So Paradoxical: The Rationale for Technology-Based Regulation, 1991 DUKE L.J. 729.

25. See Driesen, Emissions Trading, supra note 24, at 297-301 (explaining the difference between command and control regulations and performance standards).

26. See id. at 324-25. 
continue polluting at existing rates if that polluter purchases compensating "extra" reductions from some other source. ${ }^{27}$ Since these purchases will occur only if the purchased reductions are cheaper than the foregone ones, this approach offers the same quantitative contribution to environmental quality at less cost to polluters. ${ }^{28}$

The conventional account of allowance trading's advantages goes far beyond the cost-effectiveness advantage outlined above. ${ }^{29}$ The conventional account claims that allowance trading stimulates more innovation than traditional regulation, ${ }^{30}$ offers greater ease of enforcement, ${ }^{31}$ provides an incentive for continuous environmental improvement, ${ }^{32}$ and leads to more explicit democratic decisionmaking. ${ }^{33}$

Critics accept the cost-effectiveness point, but dispute much of the rest of the conventional account. ${ }^{34}$ The critics have argued that monitoring defects systematically mar overall performance more egregiously under trading than under a performance standard..$^{35}$ An allowance trading program may stimulate less innovation than performance standards and offers no greater incentives for continuous abatement than a comparable performance standard with the same compliance deadline. ${ }^{36}$ Allowance trading does not inherently make decisions more explicit and democratic. ${ }^{37}$

27. See id. at 290.

28. See Driesen. Free Lunch, supra note 5. at 36-37.

29. See Ackerman \& Stewart, supra note 6, at 172 (claiming that trading is "better, in terms of all relevant public values," than traditional regulation).

30. See, e.g., Richard B. Stewart, Controlling Environmental Risks Through Economic Incentives, 13 COLUM. J. ENVTL. L. 153, 160 (1988).

31. The conventional account, that of Professors Ackerman and Stewart, actually attributes this advantage primarily to revenue raising from allowance sales. See Ackerman \& Stewart, supra note 6, at 181-83. Subsequent promoters of the conventional account have extended this prediction to trading without the sale of permits. See, e.g., Wiener, Global Environmental Regulation, supra note 7, at 772-73.

32. See Stewart, supra note 30 , at $160,163$.

33. See Ackerman \& Stewart, supra note 6 , at 182.

34. See, e.g., Wiener, Global Environmental Regulation, supra note 7, at 720.

35. See Driesen, Emissions Trading, supra note 24, at 333-34; see also RICHARD A. Liroff, Air Pollution OfFsets: Trading, Selling, and Banking (1980) (discussing compliance difficulties in early trading experiments): RICHARD A. LIROFF, REFORMING AIR POLLUTION REgulation: THE TOIL AND TROUBle of EPA's BubBle (1986); Royal C. Gardner, Banking on Entrepreneurs: Wetlands, Mitigation Banking, and Takings, 81 IOWA L. REV. 527 (1996) (favoring trading in the wetlands context because of takings concerns despite terrible compliance defects outlined in the article); Shapiro \& McGarity, supra note 24, at 748-49 ("Emissions trading ... require[s] inspectors to monitor constantly the amount of pollution that a plant emits.").

36. See Driesen, Emissions Trading, supra note 24, at 324-27, 332-36.

37. See id. at 329 n. 185; Driesen, Free Lunch, supra note 5, at 38, 55-70; Lisa 
Economists have been even more enthusiastic about environmental taxation. ${ }^{38}$ Taxation under certain assumptions costs society less than allowance trading. ${ }^{39}$ Taxes generate revenue that the government can use to address other societal problems or even generate further environmental improvements. ${ }^{40}$

Most knowledgeable scholars recognize that appropriate instrument choice depends upon context. ${ }^{41}$ More specifically, scholars generally recognize that allowance trading will not work well when applied to pollutants that cannot be measured well. ${ }^{42}$

I use the term "allowance trading" throughout this Article because it fits a global discussion of instrument choice. This term, however, conceals what precisely the allowances allow. This is an important issue where, as in the climate change context, a large number of discrete pollutants and land use practices contribute to a global problem. While abatement of some of the gases causing climate change can be reliably measured, other gases and practices affecting climate change may be less amenable to precise quantification. ${ }^{43}$

Indeed, some international environmental problems may resist commodification and therefore trading altogether because of difficulties in measuring contributing factors. Hence, allowance trading may address some parts of an international environmental problem better than others, and global presumptions about the correct instruments are not appropriate.

Very little of the scholarship discussing instrument choice grapples with the question of how the international legal context may change instrument choice. Professor Jonathan Wiener, however, has recently argued that international allowance trading will encourage less developed countries to participate in international environmental legal regimes. ${ }^{44}$ This is an important

Heinzerling, Selling Pollution, Forcing Democracy, 14 STAN. ENVTL. L.J. 300, 324-25 (1995) (arguing that acid rain program did not achieve democratizing goal).

38. See Wiener, Global Environmental Regulation, supra note 7, at 727-35.

39. Id. at 728-29.

40. See generally id. at 730 .

41. See, e.g., id. at 681-82.

42. See Driesen, Emissions Trading, supra note 24, at 310-11; see also, e.g., DALES, supra note 1 , at 98 (arguing that trading is impracticable for "diffuse" pollution).

43. See Janey Cohen, Emissions Trading System Under Development Would Cover Processing Industry at Minimum, 22 Int'l Env't Rep. (BNA) 257 (Mar. 17, 1999) [hereinafter Norway] (noting that Norway has excluded from its proposed emissions trading system methane emissions from agriculture and landfills because it "would be difficult to monitor accurately").

44. See Wiener, Global Environmental Regulation, supra note 7, at 798. 
point because more extensive participation is vital to the success of international agreements addressing global environmental issues. ${ }^{45}$

Professor Wiener recognizes the need to analyze legal context to evaluate instrument choice. ${ }^{46}$ More broadly, Professor Wiener argues, law and economics should include legal analysis. ${ }^{47} \mathrm{He}$ points out that international legal process generally relies upon the voluntary assent of countries to create international law. ${ }^{48} \mathrm{He}$ contrasts this voluntary assent rule with the unitary fiat rule at work in domestic environmental law where a state can compel compliance. ${ }^{49} \mathrm{He}$ argues that this voluntary assent rule has important implications for global instrument choice, since it creates a need to take into account the cost of paying some states to participate. ${ }^{50} \mathrm{He}$ also argues that the "jurisdictional structure" of international environmental law affects optimal instrument choice. ${ }^{51}$

Wiener takes these insights and argues for a "presumption" that favors global allowance trading over pollution taxes and traditional regulation. ${ }^{52}$ This represents a departure from the standard analysis, which tends to favor taxes over allowance trading. He argues that the developed countries must make side payments to developing countries in order to secure their cooperation in abating pollution. ${ }^{53} \mathrm{He}$ then argues that the costs and effects of this side payment ("participation costs") make allowance trading superior to taxation as a global policy instrument. ${ }^{54}$ Primarily because of enhanced "participation efficiency," he crowns allowance trading as the presumptive winner in what he describes as an international Olympic contest

45. See id. at 689,701 .

46. See id at 681-82 (describing dependence upon context as the "first principle" of instrument choice).

47. See id. at 799 ("The 'law' in law and economics deserves closer attention.").

48. See id. at 735-42. Professor Wiener duly considers the range of decisionmaking rules used in international law and qualifies his model with appropriate caveats. He recognizes that not every decision rests wholly on consent completely free from coercion.

49. See id. at 701-04, 735-42. Professor Wiener treats writers who discuss state intervention as assuming "unitary fiat." Id. at 702 . Since most of the writers he cites live in democratic societies and some refer specifically to administrative agencies, which are subject to democratic oversight, one might think that unitary fiat embraces all state intervention. See id. Later, however, he discusses majority rule as an intermediate case between "unitary fiat" and "unanimity." Id. at 737.

50. See id at 747-50.

51. Id. at 783 .

52. Id. at 798 .

53. See id at 698-99, 750-55.

54. Id. at $760-64$. 
to identify the best regulatory instrument for global environmental regulation. ${ }^{55}$

This Article does not seek to crown a presumptive winner in an instrument choice contest because largely acontextual presumptions are not appropriate. Instead, this Article helps build a transnational theory of instrument choice. Because Wiener has thought seriously about whether the international legal context changes instrument choice theory and because the need to attract participation is important, this Article addresses many of Professor Wiener's arguments.

II

EQUITY AND COST-BENEFIT CALCULATIONS AS PREDICTORS OF ASSENT TO TREATIES

Many scholars studying international environmental law believe that countries' perceptions of the equity of proposed international agreements have a significant affect upon their decisions about whether or not to agree to substantive treaty obligations. ${ }^{56}$ This means that a regulatory instrument is not necessarily more likely to attract assent to international agreements simply because it is more cost-effective. ${ }^{57}$ Because of this, instrument choice in a transnational context requires something more than standard economic analysis.

An analysis of instrument choice should include a generic analysis of a country's actual assessment of the equities of competing instruments as part of any theory predicting what will attract countries to international agreements. ${ }^{58}$ Allowance trading may tend to appear inequitable to countries with low per capita emissions reflecting low consumption rates. ${ }^{59}$ They expect

55. Id. at $680,799$.

56. See id. at 720. See generally THOMAS M. FRANCK, FAIRnESS IN INTERNATIONAL LAW AND INSTITUTIONS (1995).

57. Cf. Wiener. Global Environmental Regulation, supra note 7, at 743-44, 760-64 (arguing that cost advantages have a large influence on participation decision). Wiener's approach bases participation predictions upon a cost-benefit function. It assumes that a calculation of self-interest based upon cost-benefit analysis determines participation. This assumption conflicts with Professor Wiener's recognition that states do not respond solely to the "benefits and costs of joining a treaty." Id . at 738. He admits that they respond to concerns about their reputation, to domestic special interests, and to other kinds of pressures. Yet his theory gives these factors no weight at all.

58. Cf. id. at 720-22 (discussing developing countries' perception of the fairness of global environmental law, but not mentioning the fact that many countries consider allowance trading unfair).

59. See Michael Grubb et AL., The Kyoto Protocol: A Guide and Assessment 97 (1999). 
developed countries to reduce their high per capita emissions in the interest of equity. ${ }^{60}$ But developed countries will use trading to avoid reducing high per capita emissions at home. ${ }^{61}$ Trading allows developed countries to purchase credits abroad in lieu of reducing per capita emissions at home. ${ }^{62}$ Furthermore, developing countries fear that trading will make their future pollution reductions more expensive because developed countries purchase the world's cheapest abatement credits early in a regime's evolution, before developing countries' obligations become effective. ${ }^{63}$ They also fear that developed countries will not invest in technologies that might eventually lower their future abatement costs. ${ }^{64}$ Allowance trading's devotion to leastcost abatement may discourage advanced technologies requiring initially expensive investments. ${ }^{65}$ These perceptions will tend to influence participation decisions.

One can adjust the design of any instrument to change the allocation of benefits and try to influence equitable perception. Professor Wiener shows how one can adjust international allowance trading to make it deliver more benefits to developing countries. But he does not compare allowance trading with

60. See id.

61. See, e.g., id. (arguing that emissions trading is inequitable because developed countries can raise their own emissions while buying cheap credits abroad); GUPTA, supra note 2, at 118 (explaining Kenyan and Indonesian views that joint implementation would encourage "profligate" lifestyles in the North). More specifically, very broad trading under the climate change regime conflicts with developing countries' equitable expectations embodied in the United Nations Conference on Environment and Development: Framework Convention on Climate Change. May 9, 1992, 31 I.L.M. 849 (entered into force Mar. 21, 1994) [hereinafter Framework Convention], that developed countries (the primary current polluters) will clean up their own emissions early in the regime's evolution and make side payments to help developing countries clean up pollution, rather than make side payments in lieu of reductions at home. See GuPTA, supra note 2, at 118; Driesen, Free Lunch, supra note 5, at $11-15,50-55$.

62. See Cooper, supra note 2 , at 422 (noting that China believed that emissions trading would shift reductions overseas, rather than reduce emissions).

63. See GUPTA, supra note 2, at 122-23; Gosseries, supra note 5, at 61-62 (noting the importance of the concern, but finding it "questionable"); see also PRODIPTo GHOSH ET AL., JOINT IMPLEMENTATION OF CLIMATE CHANGE COMMITMENTS: OPPORTUNITIES AND APPREHEnsions 26-27 (Prodipto Ghosh \& Jyotsna Puri eds., 1994) (discussing this fear); Cooper, supra note 2, at 423 (trading leaves fewer options for developing countries to reduce their own emissions).

64. See GUPTA, supra note 2 , at 129 n.41.

65. See Driesen, Free Lunch, supra note 5, at 41-46. I have argued, however, that the international community could design allowance trading to enhance technology transfer through restrictions aimed at encouraging advanced technologies. See id. at 79-81. This argument does not support the notion that allowance trading in general will increase the likelihood of developing country participation, since allowance trading may use designs that do not support technological innovation. 
competing instruments adjusted in the same way in terms of fairness perceptions.

For example, Wiener compares global taxes and allowance trading in terms of fairness. ${ }^{66}$ He points out that "global taxes" on greenhouse gas emissions "or deforestation ... could be highly regressive, taxing billions of poor people in China and India to confer benefits on wealthier people elsewhere. ${ }^{\text {"7 }}$ But he does not compare this regressive tax with a regressive tradable allowance scheme limiting the emissions and deforestation of the poor people of India and China (unless they can buy credits to justify their activities, perhaps from western electric utilities). ${ }^{68}$ Rather, he compares a highly regressive tax to a completely different tradable allowance scheme, one which is specifically "structured to achieve fairness for poorer societies." 69

Under his chosen scheme, the poor assume no immediate environmental obligation at all, but receive money to pay for abatement from developed country sources seeking abatement credits. $^{70}$ A transnational approach reveals that other instruments could also produce money for abatement in developing countries that assume no immediate obligations. One could tax developed country pollution sources and use the proceeds to pay for abatement in developing countries. And one could impose performance standards on developed countries and supplement this with a side payment funding developing country environmental efforts.

Professor Wiener prefers allowance trading with a cap constraining potential emission increases from a country receiving money for abatement. ${ }^{71}$ Such a cap, however, can exist in conjunction with any instrument.

Developing countries may well perceive a trading proposal as less equitable than a non-trading proposal delivering the same benefits. A transfer payment that earns credits toward a country's own compliance obligation will inevitably appear less generous than a transfer payment that does not.

Wiener posits a program in which developed countries

66. See Wiener, Global Environmental Regulation, supra note 7, at 721.

67. Id.

68. As this example indicates, one can design either a regressive or a progressive trading scheme. A scheme that limits the allowances of the poor will be more regressive than a scheme that limits the allowances of the rich. And the poor, unlike the rich, may not have the money to buy credits excusing their own performance of environmental obligations.

69. Wiener, Global Environmental Regulation, supra note 7, at 721.

70. See id.

71. See id. at 757, 774-75. 
receive "fewer emission allowances" (fewer than what, he does not say). ${ }^{72}$ This would suggest that purchases of pollution abatement from developing countries in Wiener's allowance trading program (although not in allowance trading generally) would constitute a genuine supplement to domestic compliance efforts created, in part, to fund developing country abatement.

Developing countries, however, may not recognize the purchase of allowances from them for credit as a form of help even under this special program. Developing countries would have no way of knowing the amount of reductions the developed countries would make without this supplemental obligation. Therefore, the increment in stringency generating the side payment is unlikely to appear like an extra to developing countries. Furthermore, supplemental reduction obligations will not appear supplemental to countries who view a developed country's baseline commitment as inadequate. Hence, the appearance of fairness problem remains, even in a program that treats developing countries especially well.

Adoption of an instrument that countries perceive as inequitable can detract from efforts to encourage effective international participation in an international agreement. ${ }^{73}$ For this reason, a serious even-handed comparative analysis of countries' actual perceptions of instruments' equitable properties must be part of instrument choice.

Surely cost considerations (not just equity) play a role in decisions to assent to a treaty. Since participating states must make side payments to attract non-participants, instruments that make these side payments cheaper cost less. But an adequate analysis must both show how this cost-effective advantage for developed countries might influence developing countries' views about whether an agreement featuring a given instrument is in their self-interest and evaluate equity problems in predicting whether cost-effective instruments will attract participation. ${ }^{74}$

72. Id at 721 .

73. See Jacobson \& Weiss, supra note 14, at 523 (“FF)or parties to implement and comply with accords, they must feel that the obligations imposed are equitable.").

74. Professor Wiener's own writing on the political economy of global environmental regulation relies on a much more nuanced view of how countries participate in international environmental agreements. See generally Wiener, Political Economy, supra note 9 . 
THE CHOICE BETWEEN TRANSNATIONAL PLURALISM AND INTERNATIONAL COORDINATION OF INSTRUMENT CHOICE AND DESIGN DETAILS

This Part examines an important legal process question: How does a decision to use a particular global instrument change the institutional structure of implementation? Comparing international allowance trading with an approach that leaves the choice of instrument largely to national governments raises significant questions about instrument choice.

This Part presents a transnational model of international environmental law that takes into account the interactions among international regimes, implementing states, and private actors. It explores the implications of global instrument choicethat is, instruments chosen at the international level- for a competing value, national pluralism in implementation. ${ }^{75}$ It explains how international allowance trading creates increased demands for international coordination in implementing agreements. These demands may increase the likelihood that countries will defect by multiplying the number of controversial legal rules countries must agree to in order to have a treaty. Alternatively, if countries fail to make the necessarily hard decisions under international law, allowance trading's increased demand for international coordination may increase the likelihood of implementation failures.

\section{A. A Transnational Legal Process Model of Global Environmental Law}

Some of the most highly developed international environmental agreements reflect a five-step process. First, countries agree (or fail to agree) to create an international environmental law, usually a treaty. ${ }^{76}$ Second, nations subject to the international agreement enact (or fail to enact) laws, regulations, or voluntary programs to induce changes in private party conduct detrimental to the environment, a national implementation phase. ${ }^{77}$ Third, private parties change (or fail to

75. I use "national pluralism" to describe a state of affairs in which treaty parties adopt regulatory regime of their choosing to comply with mandated performance standards.

76. See JURGIELEWICZ, supra note 10, at 100-12 (discussing the generation of norms through international regimes); Koh, Obey. supra note 10, at 2639, 2646.

77. Several recent studies have provided detailed discussion of this national implementation phase. See generally EFFECTIVENESS, supra note 19, at 305-658; Jacobson \& Weiss, supra note 14. This involves internalizing international norms governing environmental protection. See Koh, Obey, supra note 10, at 2646. 
change) their conduct in response to national actions, a private implementation phase. ${ }^{78}$ Fourth, national governments and international bodies assess compliance in some fashion. ${ }^{79}$ I will call this a reporting phase because many of the more sophisticated treaties require national governments to report results to international bodies. ${ }^{80}$ Fifth, the international regime responds (or fails to respond) to violations or needs to adjust the international agreements (international response phase). ${ }^{81}$ This process then repeats itself.

The voluntary assent decisionmaking rule that governs generation of formal international agreement constitutes part of a horizontal process. The vertical transnational model does not deny the importance of formal consent to treaties but emphasizes understanding subsequent conduct by nation states and private parties that might contribute to or detract from compliance. ${ }^{82}$ This Article addresses the issue of how instrument choice might affect participation. This implies a need to define adequate participation.

One might define adequate participation as national consent to an international environmental treaty imposing no substantive obligation or, even more minimally, as attendance at

78. See Edith Brown Weiss, International Environmental Law: Contemporary Issues and the Emergence of a New World Order, 81 GEO. L.J. 675, 695-96 (1993) (explaining that effective implementation requires effective private response to state implementation). By contrast, in many areas of international law a government effectively internalizes international legal norm by simply obeying it itself. See, e.g., Koh, Obey, supra note 10, at 2646-48 (explaining how the United States government eventually internalized the norms in the Antiballistic Missile Treaty).

79. See EFFECTIVENESS, supra note 19, at 47-304; Edith Brown Weiss, The Five International Treaties: A Living History, in ENGAGING COUNTRIES, supra note 14, at 89 (examining inter alia the reporting provisions of five international environmental treaties).

80. See, e.g., Weiss, supra note 79 , at $92,166$.

81. See Abram Chayes et al., Managing Compliance: A Comparative Perspective, in ENGAGING COUNTRIES, supra note 14, at 50-58 (explaining how treaty regimes use review to encourage improved compliance and stimulate treaty revision). I do not mean to suggest that these steps always occur in this order. Sometimes they do not. For example, the parties in the Montreal Protocol revised it repeatedly in response to new information, even before completion of national implementation of the Montreal Protocol. See Weiss, The Five International Treaties: A Living History. in ENGAGING COUNTRIES, supra note 79, at 138-46 (detailing the revisions of the Montreal Protocol on Ozone Depleting Substances).

82. Professor Koh has developed his transnational legal process theory as a means of explaining why nations usually comply with international legal obligations. See Koh, Home, supra note 10, at 626-27. Professor Koh, however, recognizes that violations of international law occur. See id. at 655. The record of compliance with international environmental law is mixed and, at any rate, incomplete. See generally EFFECTIVENESS, supra note 19; Jacobson \& Weiss, supra note 14. Hence, the issue of how instrument choice might influence compliance matters. 
international meetings developing international environmental law. Developing countries currently participate in international environmental governance, in the sense that they take part in deliberations and sign-up for some negotiated commitments. ${ }^{83}$ But most of them have not accepted quantitative limits under the Kyoto Protocol to the United Nations Framework Convention on Climate Change (Kyoto Protocol), one of the most important global agreements that instrument choice scholars have analyzed. ${ }^{84}$

A definition of adequate participation might require a state's assent to a quantitative or clearly substantial international environmental legal obligation. This concept of adequate participation implies a focus upon phase one of my five-step model, which Professor Koh calls international "norm enunciation," and forms the focus of analysis for horizontal approaches. ${ }^{85}$ If defined according to a horizontal model, a focus on how instruments affect participation might produce a theory of how instrument choice affects participation in the sense of producing national assent to clearly substantive treaty obligations.

A transnational model suggests that the participation relevant to global regulation does not stop with international agreement to a treaty. Rather, it must include national implementation, private implementation, reporting, and adjustment. It follows that any instrument that makes these steps more problematic or burdensome impedes effective participation.

Professor Wiener's definition of "participation efficiency" is quite ambiguous with respect to compliance issues. ${ }^{86}$ Professor Wiener identifies reduced "policy stringency" as a participation

83. See, e.g., Cooper, supra note 2 , at $430-31$ (detailing China's steps to lower its greenhouse gas emissions); Framework Convention, supra note 61, art. 4(1)(b), (d) (explaining some obligations for all parties respecting climate change); IMPLEMENTATION OF THE BERLIN MANDATE: ADDITIONAL PROPOSALS FROM PARTIES; NOTE BY THE SECRETARIAT, U.N. Doc. FCCC/AGBM/1997/Misc.1/Add.9 (1997) (discussing Tanzanian proposal on behalf of seventy-seven developing countries and China); Dora Delgado, Climate Change: Mexico Releases Furst Climate Change Plan; Focus on Energy Sector, Forest Programs, 29 Env't Rep. (BNA) 2564 (1999).

84. See Framework CONVENTION ON Climate Change. U.N. Doc. FCCC/CP/1997/L.7/Add.1 (1997) [hereinafter KYOTO PROTOCOL], reprinted without certain technical corrections in 37 I.L.M. 22 (1998) (opened for signature Mar. 21 , 1994): see also Cooper, supra note 2 , at 416-21 (discussing developing country opposition to limits on their contributions to climate change).

85. Koh, Obey, supra note 10, at 2639 (discussing norm enunciation or interpretation).

86. Wiener, Global Environmental Regulation, supra note 7, at 747-50. 
cost. ${ }^{87}$ One could view an instrument making actual compliance more problematic as less stringent. He also describes "more effective control of globally dispersed sources" as a benefit of participation. ${ }^{88}$ One might infer that an instrument widening the range of abatement opportunities while lowering the effectiveness of the controls over sources might produce more participation cost than an instrument that offered more effective abatement of an equivalent amount of total emissions involving a smaller number of sources. ${ }^{89}$ Yet he discusses compliance concerns as "other considerations," thus suggesting that they do not generally figure in calculating participation costs. ${ }^{90}$

To the extent a concept of the participation efficiency of environmental instruments neglects compliance considerations and transnational legal process considerations it becomes an engine of biased instrument choice. ${ }^{91}$ It will systematically favor instruments that buy nominal participation at lower theoretical cost over more effective instruments in actually producing environmental improvement.

\section{B. The Pluralism Option}

A transnational perspective clarifies the legal process meaning of international decisions that might affect instrument choice. Under existing institutional arrangements, international agreements generally do not directly impose regulatory obligations upon polluters. Treaties create international obligations that require participating countries to regulate their polluters. National governments then regulate polluters and choose the regulatory instruments they find most appropriate to their national circumstances.

Global environmental treaties sometimes feature agreement to a stated quantitative obligation. An international agreement reached in phase one of the legal process to require a quantity of emission reductions, for example, does not require nations to use a particular implementation technique in phase two, national law enactment. International agreements demanding national quantitative pollution abatement are, in principle,

87. Id. at 748 .

88. Id. at 747 .

89. But Wiener may mean that wider participation offers a benefit whenever more sources are involved in an environmental regime, however ineffectively. This benefit would then function as a tautological factor favoring trading.

90. Wiener, Global Environmental Regulation, supra note 7, at 771-75.

91. Cf. id. at 685 (identifying "biased policy choices" as the vice a theory of global instrument choice should avoid). 
compatible with national implementation of command and control regulation, performance standards, allowance trading, or taxes. ${ }^{92}$ Any one of these instruments, even the non-quantitative instruments, can produce a given quantity of reductions. ${ }^{93}$

The Montreal Protocol on Ozone Depleting Substances, for example, does not specify implementation mechanisms, but it does adopt a quantitative approach, limiting consumption of ozone depleting chemicals. ${ }^{94}$ Countries, however, may use any method they please to meet the quantitative targets. ${ }^{95}$ The United States alone has used command and control regulation, ${ }^{96}$ taxation, ${ }^{97}$ tradable allowances, ${ }^{98}$ and quantitative restrictions ${ }^{99}$ (a ban) to address the global problem of stratospheric ozone depletion.

The option of national taxation to produce compliance with an internationally determined quantity limit requires some highlighting. Professor Wiener generally treats price and quantity instruments as discrete categories. ${ }^{100}$ But a nation may use a price instrument as a strategy to meet an internationally determined national quantitative limit. ${ }^{101}$

This methodological pluralism allows each individual nation to tailor its instrument choice to its culture and its sources of environmental harms. It also reduces the number of difficult decisions that international institutions must make under a rule resembling voluntary assent. This increases the chances of acquiring sufficient agreement to move forward.

By contrast, an international agreement to command a specific practice limits methodological pluralism. For example, an internationally agreed upon ban on using driftnets to fish would require all countries to use this command and control approach. ${ }^{102}$ The United Nations has proposed such a ban, ${ }^{103}$ and

92. See generally Allan S. Miller, Policy Responses to Global Warming, 14 S. ILL. U. L.J. 187 (1990) (reviewing possible national responses to global warming).

93. I do not mean to suggest that a command and control approach to producing a readily quantifiable reduction is wise, I merely suggest that it is possible.

94. See Elizabeth P. Barratt-Brown, Building a Monitoring and Compliance Regime Under the Montreal Protocol, 16 YALE J. INT'L L. 519, 532-34 (1991).

95. See id. at 532 (explaining that Montreal Protocol's approach "allows states the flexibility to choose their own means of phasing out restricted chemicals").

96. See, e.g., 40 C.F.R. $\$ \S 82.34,82.36,82.156,82.158$ (1998).

97. See 26 U.S.C. §§ $4681-4682$ (1994).

98. See 40 C.F.R. $\$ 82.12$ (1998).

99. See id. \& 82.64 .

100. See Wiener, Global Environmental Regulation, supra note 7, at 706-13.

101. See generally WILLIAM J. BaUmol \& WALLACE E. OATES, THE THEORY OF ENVIRONMENTAL POLICY 162-63 (2nd ed. 1988).

102. See Convention for the Prohibition of Fishing with Long Driftnets in the South 
a number of states have agreed to bans ${ }^{104}$ because existing data support a conclusion that this particular technique is enormously destructive of fisheries. ${ }^{105}$ Moreover, enforcing compliance with this ban may prove simpler than enforcing quantitative limits upon fishing on the high seas for a wide variety of species. ${ }^{106}$ This choice of a "conduct instrument" does

Pacific. Nov. 24. 1989, art. 2, 3(1), 29 I.L.M. 1454 (entered into force May 17, 1991) [hereinafter Driftnet Convention]; Resolution on Large-Scale Pelagic Driftnet Fishing and its Impact on the Living Marine Resources of the World's Oceans and Seas, 44th Sess., Agenda Item 82(f), U.N. Doc. A/RES/46/225 (1990), reprinted in 29 l.L.M. 1555 (1990) [hereinafter Driftnet Resolution].

103. See generally Driftnet Resolution, supra note 102.

104. See Driftnet Convention, supra note 102.

105. See High Seas Driftnet Enforcement Act, 16 U.S.C. $8 \S 1826 a-1826$ c (1994) (finding that large-scale driftnet fishing is "highly destructive"); Amy Blackwell, The Humane Society and Italian Driftnetters: Environmental Activists and Unilateral Action in International Environmental Law, 23 N.C. J. INT'L L. \& COM. REG. 313, 318 (1998); Grant J. Hewison, High Seas Driftnet Fishing in the South Pacific and the Law of the Sea, 5 GEo. INT'L ENVTL. L. REV. 313, 319-23 (1993); Kelly R. Bryan, Note, Swimming Upstream: Trying to Enforce the 1992 North Pacific Salmon Treaty, 28 CoRNELL INT'L L.J. 241, 255 (1995) (emphasizing driftnet's impacts upon salmon); Leslie A. Davis, Note, North Pacific Pelagic Driftnetting: Untangling the High Seas Controversy, 64 S. CAL. L. REV. 1057, 1066-73 (1991) (discussing the existing data and its limitations); Eric J. Fjelstad, Comment, The Ghosts of Fishing Nets Past: A Proposal for Regulating Derelict Synthetic Fishing Nets, 63 WASH. L. REv. 677, 678-81 (1988) (discussing effects of discarded nets); Jane Kathryn Jenkins, Comment, International Regulation of Driftnet Fishing: The Role of Environmental Activism and Leverage Diplomacy, 4 IND. INT'L \& COMP. L. REV. 197, 206-07 (1993) (describing some of the scientific evidence supporting the congressional findings of destructiveness).

106. See Bryan, supra note 105, at 256-59 lexplaining how difficult it is to monitor catches at sea); see also EFFECTIVENESS, supra note 19, at 12 (explaining that rules on allowable discharges from ships failed, but rules requiring installation of particular equipment limiting discharges have been more effective). One can readily see why inspecting equipment would be easier than monitoring a catch. Monitoring a catch, including creatures caught inadvertently and then thrown back into the sea. would require twenty-four hour observation of fishing vessels, probably by on-board monitors. One could spot check a boat to determine whether it has a driftnet. See generally David S. Ardia, Does the Emperor Have No Clothes? Enforcement of International Laws Protecting the Marine Environment, 19 Mich. J. INT'L L. 497 (1998) (discussing problems in constructing an adequate enforcement regime for the marine environment). Some commentators have proposed tradable allowance programs for regional fisheries and have considered them enforceable. See, e.g., Kirsten M. Batkin, New Zealand's Quota Management System: A Solution to the United States' Federal Fisheries Management Crises?. 36 NAT. REsourCES J. 615 (1996); Carrie A. Tipton, Note, Protecting Tomorrow's Harvest: Developing a National System of Individual Transferable Quotas to Conserve Ocean Resources, 14 VA. ENVTL. L.J. 381 (1995). But see Anthony D. Scott, Conceptual Origins of Rights Based Fishing, in RIGHTS BASED FISHING, at 11, 28-29 (Philip A. Neher et al. eds.. 1989) (claiming that poaching is the "Achilles heel" of allowance trading in fisheries). But the trading proponents do not claim that such a system is enforceable on the high seas. They argue that the system poorly addresses bycatch, inadvertent catching of fish that gets thrown back into the ocean. Large bycatch is the primary problem with driftnets. See Batkin, supra, at 629-30. Moreover, the claims that quantity restrictions for domestic fisheries are 
not, however, preclude national, regional, or international agreements supplementing this approach with quantitative limits. ${ }^{107}$ So, it only partially constrains methodological pluralism.

On the other hand, a requirement that all countries participate in trading may discourage methodological pluralism. ${ }^{108}$ In principle, a society could supplement a trading approach with other approaches. ${ }^{109}$ But the World Trade Organization or the international body crafting the trading program may discourage, or even formally prohibit, other approaches as trade restraints. ${ }^{110}$

For example, suppose that a country decides to apply a traditional regulation to a pollution source contributing to a global environmental problem. This requirement may deny the regulated source the option of buying an emission reduction in lieu of meeting the requirement. A demand for free trade might discourage or prohibit this traditional regulation. ${ }^{11}$

enforceable rely upon systems to reconcile catch claims with the reception of fish at processing facilities. See id. at 628-29, 639; Tipton, supra, at 418-19. Such a system is much easier to implement nationally than internationally. And such a system does nothing to address bycatch.

107. See, e.g., Driftnet Convention, supra note 102, art. 3(3) (allowing national governments to implement measures stricter than those the convention requires).

108. See generally Robert W. Hahn \& Robert N. Stavins, What Has Kyoto Wrought? The Real Architecture of International Tradeable Permit Markets 4-5 (Feb. 25,1999 ) (unpublished manuscript, on file with the author and with the Ecology Law Quarterly) ("[A] fully cost-effective international emission trading program is not compatible with the notion of full domestic sovereignty regarding instrument choice.").

109. See Driesen, Free Lunch, supra note 5, at 36-37.

110. See Wiener, Global Environmental Regulation, supra note 7, at 787-89 (pointing out possibility that restrictions on allowance trading might violate the General Agreement on Tariffs and Trade (GATT)). Professor Wiener notes that GATT"s applicability is debatable. See id. A trade restriction serving environmental goals should enjoy a defense under GATT Article XX. See General Agreement on Tariffs and Trade, Oct. 30, 1947, 61 Stat. A-11, T.I.A.S. 1700, 55 U.N.T.S. 194, art. XX. But the WTO has never upheld a trade restriction under Article XX, which it construes very narrowly. See GATT Secretariat, GATT/WTO Dispute Settlement Practice Relating to Article XX, Paragraphs (b), (d), and (g) of GATT, WT/CTE/W/53/Rev.1 (Oct. 26, 1998). Even absent legal prohibitions, polluters eager to trade can be expected to pressure governments to avoid regulations that inhibit trading on the grounds that regulation interferes with the allowance trading system. Even the possibility of a trade lawbased challenge to a local pollution control measure can sometimes dissuade governments from addressing local pollution problems. See, e.g., Julie A. Soloway. Environmental Trade Barriers Under NAFTA: The MMT Fuel Additives Controversy, 8 MinN. J. Global TRADE 55, 55-57 (1999) (explaining how Canada rescinded ban on manganese-based fuel additives under pressure of a potential NAFTA challenge).

111. See, e.g., Norway, supra note 43, at 258 (statement by the chair of the Norwegian Commission for Greenhouse Gas Emissions Trading Systems that trading must not be "undermined by additional taxes or regulations ..."). 
Countries may have legitimate reasons to demand local reductions. Global and local environmental problems frequently stem from the same sources and a country may wish to improve its own environment or the environment of a particularly polluted area within the country. ${ }^{12}$ Alternatively, the country may wish to demand application of a particular technique and prohibit trading because no reliable method exists to measure the pollution from a facility. ${ }^{113}$

A country may decide to impose a pollution tax based on national emissions to meet local and international goals. An international legal regime favoring allowance trading might regard this as trade restrictive. ${ }^{114}$ Purchasing credits from abroad would not reduce the tax, but making local reductions would. One might view this as discrimination against a form of international trade, the purchase of allowances. A tax figured on the balance of allowances would not conflict with free trade in allowances. But a country may have perfectly legitimate reasons to assess the tax on the basis of actual national emissions, such as the desire to garner local pollution reduction benefits or simplification of tax administration. ${ }^{115}$

Some commentators regard restrictions on allowance trading as interference with environmental protection. ${ }^{116}$ But restriction

112. See, e.g., Wiener, Global Environmental Regulation, supra note 7, at 722 (pointing out that abatement of greenhouse gases would bring local air quality benefits).

113. This necessarlly implies an error in the initial decision to allow trading. Trading should not apply to sources that produce unmeasurable pollution. See Driesen, Emissions Trading, supra note 24, at 298, 310-11; cf. EFFECTIVENESS, supra note 19 , at 12 (explaining that laws limiting the quantity of oil discharged from ships proved ineffective because of the difficulty of monitoring tanker captains on the high seas). It seems fairly likely that even a good global decision will prove wrong with respect to at least a few sources because of imperfections in national monitoring efforts or discovery of national sources not thought about during international negotiations. The inability to measure emissions at the purchasing source does provide a good reason to disallow trading. The purchasing source will buy allowances in lieu of meeting a local obligation. If the amount of pollution at the purchasing plant cannot be verified, one cannot determine the amount of credits that must be purchased to justify foregoing compliance with the local obligation. See Driesen, Emissions Trading, supra note 24, at 310 n. 100.

114. See, e.g., Norway, supra note 43 , at 258. A full analysis of the issue of the legality of a restriction under GATT would require another article. I seek here only to establish that a potential issue would be raised, not that the GATT should prohibit pollution taxes because of a trading program. One would expect that the existence of the issue alone might inhibit a jurisdiction from enacting a tax. An unfavorable WTO ruling may require a GATT party to rescind a pollution tax.

115. See id. at 257 (noting that Norway has had green taxes in place since 1991).

116. See, e.g., KARIN ARIS ET AL., JOINT IMPLEMENTATION TO CURB ClIMATE CHANGE: LEGAL AND ECONOMIC ASPECTS 52 (Onno Kuik et al. eds., 1994) (stating that giving priority to achieving abatement of greenhouse gases suggests need for relaxed 
of allowance trading may serve national environmental protection. Generally, restrictions on allowance trading do not lower the environmental performance of an allowance trading system. ${ }^{117}$ A polluter who would like to purchase a credit, but cannot, would remain obligated to reduce her own emissions if she could not purchase an allowance. ${ }^{118}$ Restrictions on allowance trading interfere with realization of the cost savings available through trading, not environmental performance. ${ }^{119}$

Pollution taxes do not notably constrain national pluralism. One can combine taxes with other methods without direct conflicts. But allowance trading programs or traditional regulations may reduce the revenues the tax garners by reducing taxed emissions. ${ }^{120}$

\section{International Allowance Trading's Increased Demands for International Coordination}

International allowance trading increases demands for international coordination. Effective coordination requires more decisions under rules of voluntary assent. The need for more decisions creates risks of defections from the international agreement or a failure to make decisions crucial to effective implementation.

\section{Abstract Agreement About Instrument Choice}

The decision about whether or not to adopt a quantitative approach to an environmental problem is unavoidable. Trying to apply a quantitative approach to a problem that resists quantification just does not work.

"additionality" criteria); Wiener, Global Environmental Regulation, supra note 7, at 787-89.

117. See, e.g., Ann Powers, Reducing Nitrogen Pollution on Long Island Sound: Is There a Place for Pollutant Trading?, 23 CoLUM. J. ENVTL. L. 137, 186-87 (1998) (noting that the Fox River trading program under the Clean Water Act reduced biological oxygen demand as intended while only one trade took place).

118. See id. at 194-95 (explaining that water pollution trading programs generating few trades have brought about pollution reductions); Protection of Stratospheric Ozone, 53 Fed. Reg. 30,566, 30,589 (1988) (explaining that promulgation of an allocation of CFC production quotas would produce compliance with Montreal Protocol, even without anticipated promulgation of transfer provisions).

119. See Driesen. Free Lunch, supra note 5, at $83 \mathrm{n.414}$ (explaining why an argument confusing a foregone opportunity to purchase a credit with a foregone emission reduction is wrong).

120. Cf. Wiener, Global Environmental Regulation, supra note 7, at 731 (explaining that the revenue raising goal of a pollution tax generally conflicts with its environmental goal anyway because reduced emissions reduce the tax base). 
If, however, one can quantify contributions to global environmental problems, several instruments may work. Parties to a treaty can adopt a quantity limit without specifying instruments, or they can collectively dictate a global choice about how to go about meeting the quantitative objective.

A global choice about instruments transfers a decision that individual nations might make after adoption of quantitative targets under a rule of unitary fiat to a global forum, where the principle of voluntary assent applies. This means that it becomes harder to move forward because international agreement about quantitative targets for each nation no longer suffices. An agreement must ensue about instrument choice as well.

One cannot have international allowance trading without international agreement. Hence, a decision to leave instrument choice wholly to national governments involves a loss of cost savings from international allowance trading.

Choosing an instrument at the international level, however, increases the risk of non-participation by injecting another potentially divisive issue into a global debate. The climate change regime provides an example of this problem. Once the United States decided that it preferred international trading as an instrument, it insisted on an international decision authorizing it. ${ }^{121}$ The United States could authorize domestic allowance trading without an international agreement. ${ }^{122}$ But it would save more money if the international community would authorize international allowance trading. This issue has proven divisive and came close to scuttling agreement to the Kyoto Protocol. ${ }^{123}$ Recent follow-up meetings in Buenos Aires and Bonn failed to produce an international accord on ground rules clarifying the ambiguous trading provisions in the Kyoto Protocol. ${ }^{124}$

To the extent nations negotiating future agreements feel that a particular instrument choice favors them, they may also insist on international adoption of their favored instrument as part of

121. See James H. Searles, Analysis of the Kyoto Protocol to the U.N. Framework Convention on Climate Change. 21 Int'l Env't Rep. (BNA) 131, 133 (Feb. 4, 1998) (noting that the United States has demanded emissions trading in exchange for legally binding emission reductions).

122. See Driesen, Free Lunch, supra note 5, at 36.

123. See Brendan P. McGivern, Introductory Note to Kyoto Protocol, Dec. 10, 1997, 37 I.L.M. 22, 26 ("The negotiations in Kyoto nearly collapsed over the issue of emissions trading.").

124. See Buenos Aires Report, supra note 4, at 22-23 (failing to agree upon ground rules for emissions trading, the parties agreed to a work program for subsidiary bodies); see also UNITED NATIONS, REPORT OF THE CONFERENCE OF PARTIES AT ITS FIFTH SESSION, U.N. Doc. FCCC/CP/1999, at 32-35 (1999). 
new global regimes. Scholars should think about whether the advantages that internationally chosen instruments offer really justify the risks of failure that attend the making of international, rather than national, instrument choices.

\section{International Coordination of Design Details}

A responsible global choice of international allowance trading requires international agreement about design details essential to the program's effectiveness. This necessitates still more international decisionmaking under a voluntary assent voting rule.

Allowance trading greatly increases the complexity of responsible decisionmaking. The need for agreement on numerous rules governing international transactions could increase the risk of defections. Or, if the international community does not face the complex issues that require resolution, it might fail to enact enough good design decisions to make allowance trading work reasonably well. ${ }^{125}$ If this occurs, then a disguised decrease in stringency has occurred to buy nominal participation. Widespread international underperformance could follow formal assent to an agreement.

International trading multiplies compliance challenges. ${ }^{126}$ It significantly complicates the latter four phases of my transnational model. ${ }^{127}$ One can check compliance by comparing national emission reductions against national commitments under transnational pluralism. Each country could choose taxes, allowance trading, traditional regulation, some combination of these approaches, or a different approach entirely; international compliance determinations could focus primarily upon the question of whether each country's reported aggregate emissions had met the agreements' national targets.

125. For an example of the kind of critical problem that could greatly reduce the performance of a program, see ENVIRONMENT DIRECTORATE, ORGANISATION FOR ECONOMIC CO-OPERATION AND DEVELOPMENT, EXPERIENCE WITH EMISSION BASELINES Under the AIJ Pilot Phase, enV/Epoc(99)23/Final (May 28, 1999) (OECD Information Paper) (discussing the inconsistent baselines in joint implementation projects in the absence of international rules governing them).

126. See Richard B. Stewart \& Jonathan B. Wiener, The Comprehensive Approach to Global Climate Policy: Issues of Design and Practicality, 9 ARIz. J. INT'L \& COMP. L. 83, 108-09 (1992) (describing additional administrative tasks that trading creates); Wiener, Global Environmental Regulation, supra note 7, at 787.

127. These latter four phases include national law enactment, private party compliance, compliance assessment, and international adjustment. See infra Part III.A. For an explanation of how international trading complicates compliance challenges in these four phases, see infra Part III.C. 2 and accompanying notes. 
International allowance trading, however, precludes this approach to judging national compliance. A country whose actual emissions exceed a target may be either in compliance or out of compliance under an allowance trading regime, depending on whether it has purchased valid credits from another country (or its nationals) sufficient to cover the exceedance. ${ }^{128}$ Similarly, a country that physically meets a target, may be in compliance or out of compliance, depending on whether it has sold national emission reductions to another country (or its nationals). ${ }^{129}$ Hence, a choice to pursue international allowance trading complicates phases four and five of the transnational legal process, reporting about national compliance and international response. This implies the need for international agreement modification reporting and compliance assessment to fit international allowance trading. ${ }^{130}$

A treaty might allow, or even mandate, national legal authority for private international trades. ${ }^{131}$ Private party trading augments potential private party cost savings, but may generate more administrative costs for national governments.

Allowing private parties to trade means that countries must track private international transactions and compare them with foreign plans to know whether or not each country has complied

128. An example will demonstrate this. Suppose that a world consisting of two countries agrees to limit pollution. now at 200 tons a year, to 100 tons a year worldwide. If each country currently has 100 tons of emissions, a treaty can allocate a 50 ton reduction obligation to each country to achieve the 100 ton cut. At the end of the compliance period, a country would be in compliance if its aggregate emissions were 50 tons or less ( 100 minus 50 ).

Suppose the treaty authorizes allowance trading and country $B$ has 60 tons of national emissions at the end of the compliance period. It appears that country $B$ has violated the requirement that it emit only 50 tons. If, however, country $B$ purchased a valid 10 ton reduction credit from A, country $B$ should be judged compliant. This 10 ton credit should reduce country B's national 50 ton reduction obligation to 40 tons.

I am assuming here that the treaty contains a clear and appropriate definition of compliance under trading. I have argued elsewhere that trading tends to complicate understanding of compliance and leads to vague definition of national commitments. See Driesen, Free Lunch, supra note 5, at 58-62.

129. Suppose at the end of the compliance period, country $A$ has 50 tons of national emissions under a treaty requiring a 50 ton cut to a 50 ton level, but authorizing trading. This apparently compliant national total may indicate noncompliance. Country A could have sold 10 tons of reductions to country $B$, which would then make less national reductions because of the credit. Country A should have made a 60 ton reduction in order to comply (50 tons of required national reductions plus the 10 tons sold to $B$ ).

130. See Stewart \& Wiener, supra note 126, at 108 (trading would require a registry to keep track of trades and make sure that existing inventories are consistent with the record of trades).

131. See Wiener, Global Environmental Regulation, supra note 7, at 788. 
with a treaty obligation. ${ }^{132}$ Finding out whether any particular country has complied involves a potentially complex tracking operation. ${ }^{133}$ A risk exists that both countries will claim credit for the same reductions. ${ }^{134}$ Such double counting would allow all countries to plausibly claim compliance even when environmental performance did not meet a treaty's requirements.

Furthermore, detecting problems as the compliance effort evolves, instead of after the deadline for meeting a cap (that is, during the national and private implementation phases), may help national governments avoid failures. ${ }^{135}$ International trading greatly complicates this process because national governments will develop environmental measures and plans on varying schedules (absent highly unlikely compliance with an unlikely international agreement to parallel deadlines for the development of national implementing laws). One country cannot figure out whether a purchased credit is surplus to the selling countries' compliance effort until the selling country completes its plans. ${ }^{136}$

International allowance trading raises questions about which national government (or international agency) should oversee monitoring of credits earned in one jurisdiction and then sold abroad and which should accept responsibility for problems. ${ }^{137}$ Worse, it creates an incentive to buy credits from hosts in the countries least able to accurately monitor performance of environmental measures. ${ }^{138}$ If one can exaggerate credits from a project in a nation, then this can sharply reduce compliance costs at the expense of environmental protection. To the extent these problems can be solved, they require international legal rules, which will require the voluntary assent of all participating governments. ${ }^{139}$

132. See Driesen, Free Lunch, supra note 5, at 64-65.

133. See id.

134. See id.

135. See id. at 63-65.

136. See id.

137. See Green \& Sands, supra note 3 , at 84.

138. See Driesen, Free Lunch, supra note 5, at 65-66; see also Robert Stavins, Policy Instruments for Climate Change: How Can National Govemments Address a Global Problem?, 1997 U. CHI. LEGAL F. 293, 312 (discussing incentives for parties to joint implementations to exaggerate credit's value). Trading will tend to shift reduction claims from developed to developing countries that lack sufficient administrative capacity to monitor reductions because developing countries offer lower compliance costs. See Jacobson \& Weiss, in ENGAGING CoUNTRIES, supra note 14 , at 23 (noting that record of compliance with international accords has been poorer in developing countries because they have weak administrative capacity).

139. See generally Cooper, supra note 2 , at 423 (discussing debates at Kyoto about tracking credits). 


\section{a. Non-Capped Programs}

Thus far, I have described generic issues that allowance trading will generate in international fora, almost regardless of design. But other issues exclusively exist in certain designs.

Professor Wiener seems to favor a particular form of trading, one that caps emissions in all trading countries. ${ }^{140}$ But acceptance of this form of trading implies a debate about the relative value of competing types of environmental benefit trading. ${ }^{141}$ His proposal might, for example, require a modification of the Kyoto Protocol, which contemplates some trading with countries lacking caps. ${ }^{142}$ Looking at the difference between capped and uncapped programs may foster appreciation of the complexity a responsible debate about a cap would have. ${ }^{143}$

Professor Wiener treats purchases of allowances from countries without caps as a subsidy that might perversely augment emissions under the approach currently found in the

140. Professor Wiener seems to define allowance trading as including a cap limiting the "aggregate amount of entitlements" to harm the environment. Wiener, Global Environmental Regulation, supra note 7, at 710 . Furthermore, he draws a distinction between formal allowance trading, which involves trades between countries subject to caps, and "joint implementation for credit," which involves trades with countries lacking caps. Id. at 713; cf. Driesen, Free Lunch, supra note 5, at 31 n.181 (arguing that scholars' inconsistent use of the term "joint implementation" makes the distinction between trading and "joint implementation" unclear). He then suggests that a trading program that authorizes purchase of allowances from countries lacking caps could constitute a subsidy likely to augment emissions in the uncapped countries. See Wiener, Global Environmental Regulation, supra note 7, at 757. He tentatively calls for sharp discounting of credits from uncapped countries and a rapid transition to "full formal allowance trading," that is, trading with caps. Id.

141. See Driesen, Free Lunch, supra note 5, at 32-35 (discussing the difference between emissions trading and broader environmental benefits trading). See generally Richard E. Ayres, Developing a Market in Emission Credits Incrementally: An 'Open Market' Paradigm for Market-Based Pollution Control, 25 Env't Rep. (BNA) 1522 (Dec. 2, 1994) (contrasting cap and trade model with an "open market" model and a hybrid command-and-control system); Industry-Led Initiative on Emissions Trading Preparing Proposal for Draft Rule in Ontario. 22 Int'l Env't Rep. (BNA) 258 (Mar. 17, 1999) (describing an industry proposal for an "open market" trading program without caps).

142. See Kyoto Protocol, supra note 84, art. III, $\$ 12$; see also id. Annex B \& 37 I.L.M. at 34, 38, 43 (not listing cuts from developing countries); Driesen, Free Lunch, supra note 5, at 34-35. Global Environmental Regulation's recommendation to discount credits probably does not require a modification of the Kyoto Protocol, but Wiener's suggestion to press the transition to allowance trading under global caps would require an amendment. Wiener, Global Environmental Regulation, supra note 7, at 757 .

143. See generally Brennan Van Dyke, Note, Emissions Trading to Reduce Acid Rain, 100 YALE L.J. 2707, $2711 \mathrm{n} .27$ (1991) (describing a cap and trade program, the United States acid rain program). 
Kyoto Protocol. ${ }^{144}$ An international debate about whether to allow trading without caps should involve competing claims about how large an effect this particular form of "leakage" would have. ${ }^{145}$

International trading creates many other equally important issues. Trading could allow polluters to claim credits for reductions incident to normal demand shifts within countries. ${ }^{146}$ Polluters in capped countries will purchase reductions from uncapped countries that would have occurred anyway unless internationally agreed upon rules constrain them. ${ }^{147}$ They will not, however, assume debits for emission increases that occur anyway in uncapped countries. As a result, the routine ups and downs of business as usual in uncapped countries can generate credits that will excuse required reductions in the capped countries. ${ }^{148}$ This can occur even if overall emissions increase in the uncapped country.

To illustrate the effect of credits for incidental reductions, assume that a capped country has only one plant emitting 100 tons of a globally harmful pollutant, and the country requires a 50 ton pollution reduction from this plant. An uncapped developing country has two plants, each emitting 50 tons $(100$ tons total). Our little world emits 200 tons of pollution. In the developing country, one plant raises its production and increases its emissions from 50 to 100 tons, driving the other 50 ton emitter out of business.

Absent trading, capped country emissions drop to 50 tons and uncapped emissions remain constant at 100 tons. World emissions (assuming no other countries exist) have dropped from 200 to 150 . With trading, the developed country plant may purchase a 50 ton credit from the plant shutting down. ${ }^{149}$ This phantom credit allows it to forego making its 50 ton reduction. World emissions have stayed the same, 200 tons $(100+100)$. Trading has robbed the world of the reductions an environmental effort would otherwise produce.

144. See Wiener, Global Environmental Regulation, supra note 7, at 757 .

145. Id. at 695 (discussing estimates of leakage effects varying from $4 \%$ to over $100 \%$ of emission abatement).

146. This problem of demand shifts within countries goes beyond the problem of leakage between countries that Professor Wiener discusses. Cf. id. at 692-97.

147. See, e.g., Citizens Against the Refinery's Effects v. EPA, 643 F.2d 183, 184-85 (4th Cir. 1981) (allowing Virginia to offset petroleum refinery emissions with reductions realized through state use of different asphalt to coat highways).

148. See Driesen, Free Lunch, supra note 5, at 66-67.

149. See Navistar Int'l Transp. Corp. v. EPA, 941 F.2d 1339, 1344 n.10 (6th Cir. 1991) (describing use of credits from some shutdown sources to justify lack of controls on other sources). 
Credits for production slowdowns or process changes could similarly lessen the performance of an environmental program. An uncapped pollution source could sell credits when its production slows down and its emissions decrease. When an uncapped pollution source's production increases and emissions rise, however, nobody would assume responsibility for generating a compensating reduction. Indeed, certain routine shifts in what is produced by a plant, assuming no environmental effort at all, could generate credits.

A similar problem could occur if polluters try to claim credits for reductions incident to local pollution control efforts. ${ }^{150}$ For example, a country may limit coal burning in order to solve local environmental problems. The polluter subject to this restriction may then sell a credit reflecting its required performance to a polluter elsewhere, who uses the credit to justify not having to meet otherwise applicable limits. Absent trading, two reductions would occur instead of the one. ${ }^{151}$

Since the incremental cost of producing credits that would occur anyway is zero, these kinds of credits will be far cheaper than any credit reflecting an actual fresh effort to protect the environment. And the bargain basement price will make these credits attractive to buyers of credits.

On the other hand, advocates of "open market trading" (that is, purchasing credits from uncapped sources) point out that cheaper reduction opportunities will exist when one can trade outside of a cap. ${ }^{152}$ If they are right, there may be a tension between maximizing cost-effectiveness (or at least lower cost) and adequate environmental protection. In any case, this potential advantage will make proposals to cap trading controversial.

\section{b. Capped Programs}

An effective cap on emissions in every country may address the problem of incidental credits and the problem of subsidy-

150. See, e.g., Oregon Envtl. Council v. Oregon Dep't of Envtl. Guality, Civ. No. 91-13-FR (D. Or. Sept. 24, 1992) (describing use of a twenty-year-old emission control to justify not complying with subsequently promulgated obligation).

151. See generally RICHARD R. POWELl, POWELl ON REAL PROPERTY II 865.5A[9], at 79A-271 (David M. Driesen rev., 1994).

152. See Ayres, supra note 141, at 1526; Open Market Trading Rule for Ozone Smog Precursors, 60 Fed. Reg. 39,668, 39,671 (1995) (proposed Aug. 3, 1995). While the United States Environmental Protection Agency (EPA) never adopted this proposed rule, it has informally encouraged states to adopt open market trading programs, and several states have done so. See, e.g., ILl. ADMIN. CoDE tit. 35, \$§ 205.100-.760 (1997); Mich. Admin. CODE r.336 (1996); 30 TEX. Admin. CODE $§ 101.29$ (West 1997). 
induced emission increases. A cap restrains the subsidies' negative effects, as Professor Wiener points out. ${ }^{153}$ It also, for reasons set out in the margin, addresses many of the incidental credit problems. ${ }^{154}$

Legal scholars, however, need to think about the meaning of a cap as a matter of transnational legal process. One might assume that a national commitment to a pollution target in an international treaty represents a sufficiently effective barrier to subsidy augmented leakage and incidental credits to allow for successful allowance trading. But this is debatable. Clearly, a country responding to the cap in the national implementation phase by quantitatively limiting each of its relevant pollution sources provides a real cap. ${ }^{155}$ Trades between two countries that have done this effectively provide little potential for leakage or incidental credits. ${ }^{156}$ This transnational comprehensive strategy, while certainly environmentally desirable, would greatly strain the administrative capability of many countries, especially poorer countries that would tend to generate most of the credits in a global allowance trading system. ${ }^{157}$ Wiener points out that just about "every human activity directly or indirectly emits" the greenhouse gases that contribute to global climate change. ${ }^{158}$ This suggests formidable administrative obstacles to comprehensive national caps addressing Wiener's primary

153. See Wiener, Global Environmental Regulation, supra note 7, at 756-57.

154. An effective cap contains the demand shifts within caps, so that they do not matter. In the example discussed above, a 100 ton source purchased credits from a plant reducing emissions by 50 tons because of a shutdown. As a result, an environmental plan to get 50 tons of reductions from the world did not work.

Suppose, however, that all of the plants in the problem had meaningful caps at or lower than current actual emissions. Both developing country plants would be prohibited from exceeding a 50 ton limit and the developed country plant would face a cap of 50 tons as well (a reduction demand). Now the developing country plant increasing production cannot emit more than 50 tons without purchasing credits from the plant that is shutting down. If this occurs, the developed country plant will have no credits available and will have to reduce emissions by 50 tons. Because of the caps, even with levels set at 50 tons, reduction occurs worldwide as planned.

155. This resembles the acid rain program, since the electric utilities that program regulates emit almost all of the sulfur dioxide contributing to acid rain. See Byron Swift, The Acid Rain Test. ENVTL. F., May-June 1997, at 17 (arguing that the cap is more important to acid rain program's success than trading).

156. The problem of two countries taking credit for the same reduction might exist even under a cap. This discussion, however, will assume this problem away. It might be possible to design a program to address this problem effectively.

157. See Jacobson \& Weiss, in ENGAGING COUNTRIES, supra note 14, at 25-26 (explaining that generally national compliance diminishes as the number of sources to be monitored increases and that developing nations tend to implement treaties poorly).

158. Wiener, Global Environmental Regulation, supra note 7, at 692. 
example of a global environmental problem. ${ }^{159}$

Absent an international allowance trading system mandating this particular type of broad cap, countries may choose a different strategy. ${ }^{160}$ They may regulate a select group of sources intensively and leave the others alone. ${ }^{161}$ If a foreign country purchases credits from the uncapped sources, however, this reintroduces subsidy and incidental credit problems, despite the existence of national quantitative commitments. ${ }^{162}$

In theory one could solve many of these problems by implementing a comprehensive cap. But my point is not that each of these problems is unsolvable in theory. My point is that the need to solve them under a rule of voluntary assent generates significant problems. The existence of these problems means that agreement upon national targets and the adoption of a trading instrument are not enough. Rather, international agreement upon significant features of instrument design and institutional structure become necessary. The choice to implement a global instrument that generates international transactions, rather than national instruments, creates this legal

159. See, e.g., Norway, supra note 43, at 257 (explaining that Norway has excluded methane emissions from agriculture and landfills from its proposed emissions trading system because of monitoring difficulties). See generally Carol M. Rose, The Shadow of the Cathedral, 106 YALE L.J. 2175 (1997) (discussing the role of shadow examples in theoretical articles). Some complex global problems may resemble the problem of tropospheric ozone in the diversity and number of potential sources that contribute to the problem. EPA has not capped emissions of sources contributing to tropospheric ozone, but has authorized limited trading, with rather poor results. See Driesen, Emissions Trading. supra note 24, at 314-16 nn.120-27 and accompanying text.

160. See Hahn \& Stavins, supra note 6 , at 10 (trading regime depends in fundamental ways upon domestic instrument choice).

161. See, e.g.. Janey Cohen. Denmark: Nation Considering Cap, Trade Proposal for GHG Emissions from Electricity Sector, 22 Int'l Env't Rep. (BNA) 256 (Mar. 17, 1999) (explaining that Denmark is imposing a cap and trade program upon the electricity sector only because "it is the largest single emitter").

162. National commitments under international law do not restrain private sources of environmental harm. Only national implementing laws do that. A country using a limited cap to meet a quantitative commitment should estimate the pollution the uncapped sector would generate and plan on providing enough regulation under the cap to achieve the international commitment for net total emissions. As long as the capped and uncapped sectors were unrelated enough to discourage leakage, this may work reasonably well, absent trading. But if another country purchases credits from the uncapped sector, this subsidy may raise emissions in ways unanticipated by the host nation. It may find out about the raised emissions in an unregulated sector too late to adjust national regulation. Even if no subsidy induced increases occur, the purchasing country may take advantage of demand shifts within the uncapped sector to claim credits. In that case, even if the uncapped total within the host country remained as anticipated, another country's purchases would produce double counting. 
process problem.

\section{c. Legal Assumptions in Compliance Discussions}

Most serious claims that allowance trading will work properly depend upon an assumption that some institution will design an elaborate set of design rules to guard against problems and create opportunities. But this assumption may be problematic at the international level, where decisions require the unanimous consent of many nations.

For example, Professor Wiener argues that international allowance trading adds "useful enforcement tools." 163 These include the "ability to debit the violator's allowance account for past exceedances or even expel the violator from the market."164 Presumably, enactment of these "enforcement tools" would require international agreement. However, nations may disagree about the appropriateness or effectiveness of expelling a violator from an emissions trading market and about whether a debit in an account really is an enforcement tool or just a means to track what is going on.

Professor Wiener also discusses a potential "treaty obligation on national governments to subassign allowances to private sources." ${ }^{165}$ Resolution of the question of whether subassignment should be allowed, let alone required, has already generated great controversy in the climate change debate. ${ }^{166}$

This discussion should include consideration of subassignment's implications for compliance. Wiener argues that fraudulent sales are unlikely because national governments are repeat players. ${ }^{167}$ But a transnational legal process decision to allow private parties, not just governments, to trade may change the analysis. Even if one assumes that governments trade repeatedly and therefore will not engage in fraudulent sales, one might ask whether private parties are "repeat players" unlikely to engage in "fraudulent sales." If the potential problem of fraud is taken seriously, the sub-assignment issue may prove difficult to resolve.

And trades between private parties raise important

163. Wiener, Global Environmental Regulation, supra note 7, at 772.

164. Id. at $772-73$.

165. Id. at 788 .

166. See, e.g., Gary E. Marchant, Freezing Carbon Dioxide Emissions: An Offset Policy for Slowing Global Warming, 22 ENVTL. L. 623, 641 (1992) (claiming that international trades between private sources pose "insurmountable problems").

167. See Wiener, Global Environmental Regulation, supra note 7, at 773. 
compliance problems more subtle than outright fraud. Suppose that one country imposes a carbon tax as a strategy to reduce greenhouse gases. One might ask whether a carbon dioxide emitter in the taxing jurisdiction should be allowed to sell credits for reductions it makes. Since this creates a risk of double counting reductions, international law could bar carbon taxes, forbid polluters paying the tax from selling credits, or codify complicated rules trying to separate tax induced reductions (which might not be available for purchase) from other reductions a polluter subject to the tax might make (which might be sold for credits). ${ }^{168}$ Such an issue may prove difficult to resolve by unanimous consent.

A decision to adopt an international trading program dependent upon international transactions shifts responsibility for instrument design from national governments to international institutions. ${ }^{169}$ This shift raises important questions about the administrative capacity of international institutions. If the international institutions duck these design questions (or fail to resolve them well), then we may have participation consisting of agreement in phase one, followed by undetectable noncompliance in the implementation phases (or redefinition of compliance to fit poor performance). A transnational legal process approach shows that adoption of international allowance trading increases the number and difficulty of decisions under voluntary assent. It increases risks of non-compliance, since only unanimous agreement to numerous good decisions at the international level will produce an adequately designed program.

IV

COMPARATIVE ANALYSIS USING THE TRANSNATIONAL APPROACH

This Part shows that a transnational legal process analysis changes comparative analysis of instruments. In particular, it

168. Professors Hahn and Stavins argue correctly that cost minimization supports allowing sources subject to carbon taxes to generate credits. See Hahn \& Stavins, supra note 108 , at 14 . But this would weaken environmental performance, unless the credits are limited to abatement costing more than the marginal rate of the tax. Implementing a fine distinction between reductions motivated by a tax and those undertaken for other reasons would require the government to acquire reliable marginal abatement cost information for discrete parts of abatement activities. This potential solution raises critical feasibility issues.

169. See Richard B. Stewart et al., U.N. Conf. on Trade and Dev., Legal Issues Presented by a Pilot Int'l Greenhouse Gas Trading System Among Countries with Binding Emission Targets Under the FCCC, UNCTAD/GDS/GFSB/Misc. 1, at 2 (1996) (assuming that international law, rather than national laws, would govern "any international system for trading emissions between ... States ... "). 
casts doubt on Professor Wiener's arguments for the superiority of allowance trading over pollution taxes and traditional regulation. A transnational approach differentiates between the government's role and that of private parties in order to better understand the legal process. ${ }^{170}$ Professor Wiener's most provocative conclusion, that allowance trading is a superior instrument to a pollution tax under a voluntary assent voting rule, only holds true under very limited transnational legal process assumptions.

\section{A. Whose Cost Counts? Comparing Taxes and Allowance Trading}

Most economists think that a pollution tax costs a society less than allowance trading aimed at the same goal under standard economic assumptions. ${ }^{171}$ This would suggest that cost considerations at any rate favor taxes, even in the global context. The relative costs of taxes and trading should not change under a rule of voluntary assent and the related principle that one must consider participation costs. If a society can achieve a stated reduction goal through taxes more cheaply than through allowance trading, then side payments purchasing participation from reluctant states should be cheaper when the recipient of the side payments uses taxes to reduce emissions.

The intuition that a side payment should not change the relative merits of taxes and allowance trading, however, may rest upon a transnational legal process assumption. One might assume that the government, rather than private polluters, receives the side payment. ${ }^{172}$ The government chooses an instrument to deliver the aggregate reductions that the side payment purchases. Or one might assume a transnational pluralist approach, under which the private parties receiving payments subsidizing environmental improvement are not the same private parties that must pay the tax. Under these scenarios, the cheapest mechanism (taxes) should produce the cheapest aggregate reductions and hence generate the lowest minimum charge for a side payment.

Professor Wiener, however, concludes that under voluntary assent, allowance trading is superior to environmental taxation.

170. See, e.g., Koh, Home, supra note 10, at 646-51 (describing various state and non-state actors' roles in generating compliance with international law).

171. See Wiener, Global Environmental Regulation, supra note 7, at 727-35.

172. In places. Professor Wiener seems to have this model in mind. See, e.g., id. at 755 (discussing compensation to the "source state"). 
He does not explain what, if any, transnational legal process assumption leads to this conclusion. One cannot analyze a tax without considering who pays the tax, who levies it, and, in the context of global environmental law, who gets side payments. In other words, one must consider whose costs count in considering how the costs of a tax might affect national participation decisions.

Professor Wiener concludes that taxes require larger side payments than allowance trading, in part, because the state paying the tax must pay more abatement cost than it would under a tradable allowance program unless allowances are sold. ${ }^{173}$ Professor Wiener argues that the state must pay the abatement cost necessary to avoid some taxes, plus the taxes on residual emissions not reduced. ${ }^{174}$ Presumably, a taxed polluter would reduce emissions where abatement costs are lower than the tax rate, thereby generating some abatement costs. ${ }^{175}$ But the polluter would not reduce emissions when abatement costs exceed the tax rate and would remain liable for the tax on the residual emissions. ${ }^{176}$ Hence, if the state faces the same costs as its taxed polluters, it would demand compensation for all taxes on residual emissions plus all pollution control expenditures made to partially avoid the tax.

Professor Wiener's argument that a tax would cost the state more than allowance trading makes sense if one assumes that the state's net cost equals that of the polluters within the state. ${ }^{177}$ One can imagine some legal contexts where this makes sense. For example, if an international body levies a pollution tax upon a state that owned all of the relevant industry, then the tax would involve a pure cost to the state and conform to Professor

173. Professor Wiener explains that the "side payment will ... have to be proportionately larger" if a tax is used because the taxing jurisdiction will demand compensation for both its abatement cost and its cost of paying the tax on its residual emissions. Id. at 760 . Later he explains that the cost of the side payment under allowance trading would equal that of the tax if pollution sources must pay for their allowances. See id. at 764.

174. See id. at 760,763 .

175. See BAUMOL \& OATES, supra note 101, at 52-53.

176. See id.

177. Professor Wiener discusses a tax upon "sources," a term which conventionally refers to activities within a country that private entities such as industries and individuals carry out. Wiener, Global Environmental Regulation, supra note 7 , at 760 . But he then moves to a discussion of a "source country." Id. at 761 (emphasis added). Wiener's graphic illustrations of abatement costs show precisely the situation that a polluting industry would confront. See id. at 761-63. But in context, Wiener's text uses the term "source" to refer to countries. See id.; see also id. at 751-52 (referring to China as a major "source" and then claiming that taxes "may be" participation inefficient "because taxes impose the highest cost on sources"). 
Wiener's analysis. The state would pay all of the tax and the international body would receive all of the revenue. Perhaps this equation of the state and its polluters can extend to any situation in which the revenues leave the state. ${ }^{178}$

However, the assumption of international tax collection seems far-fetched. As Baumol and Oates have pointed out, "There is . . . no world government with taxing prerogatives." 179

One might assume instead that an international environmental taxation regime would follow the same legal process model that has governed most international environmental law. An international treaty might require or encourage each country to tax its polluters to meet international environmental goals. And it might allow the state, but not the polluter, to keep the revenue.

It would seem that the state would receive a pure benefit from the tax with no cost. The state collects the tax; it does not pay it. This would imply that this international environmental taxation regime would have no participation cost and every state should want to join in the treaty.

This view of the state as a self-interested rational economic actor may seem too narrow. Perhaps we should view the state as a proxy for a society as a whole.

But viewing the state as a proxy for society does not help Professor Wiener's analysis either. A society, even the society of a polluting state, includes more activities than just pollution. ${ }^{180}$ Although a pollution tax is a burden on polluters, it presumably generates government revenues that pay for something of value to the society (for example, police and fire protection or childhood vaccinations). ${ }^{181}$ Absent transaction costs or

178. If one assumes that the state acts as a proxy for the society as a whole, then one could say that the state pays the polluters' abatement cost and receives no compensating revenue even if the state does not own the industry. Even the special case under which Professor Wiener's analysis appears correct shows that participation costs matter. Scholars have proposed having an international body collect and spend taxes, and one could imagine changes in international legal process making this possible. See, e.g., Michael Hoel, Efficient International Agreements to Reduce $\mathrm{CO}_{2}, 12$ ENERGY J. 93, 98 (1991) (proposing that an international agency impose a tax on each country based on national $\mathrm{CO}_{2}$ emissions).

179. See BAUMOL \& OATES, supra note 101 , at 279.

180. Professor Wiener's cost analysis posits a pure polluting state collecting a side payment from a pure victim state. See Wiener, Global Environmental Regulation, supra note 7 , at 761 . But his definition of a pure polluter does not posit that the pure polluter state has pollution as its sole activity. Rather, he posits that a pure polluter state experiences none of the global environmental problems its pollution contributes to. See id. at 699-700. A model that posits a society that pollutes and does nothing else would have no use in the real world.

181. See Hal R. VARIAN, INTERMEdiate MiCroeconomic: A MODERn APPROACH 294 
deadweight losses, the net cost of the tax to society should be zero. ${ }^{182}$ With these costs, the cost of the tax to society should equal the transaction costs or any deadweight loses, not the abatement costs to the polluters. If these transaction costs are less than the cost of abatement under allowance trading, which generates no revenue, then the transfer payment necessary to persuade a country to tax should be lower than under allowance trading.

This point is important to Professor Wiener's argument. Professor Wiener explains why many economists think that taxes are cheaper than allowance trading under unitary fiat. ${ }^{183}$ He does not explicitly claim that any of these factors change under voluntary assent. But an implicit legal process assumption, an assumption that an international body instead of a taxing nation collects the tax, can make one of these factors, the positive effects of government revenue, disappear from the equation. ${ }^{184}$ Change the legal process assumption and the cost-effectiveness advantage of a tax over allowance trading reappears.

Professor Wiener identifies another "participation efficiency" problem with taxes that disappears under fairly standard transnational legal process assumptions. ${ }^{185} \mathrm{He}$ has argued that a side payment to polluting states negates the tax's effect. ${ }^{186}$ This is correct only if one assumes that the state would pass the side payment on to the polluter. The state, however, need not pass the side payment on to polluters. It may spend it on other programs such as health care, or it could turn around and subsidize further abatement under a cap with all or some of this money. ${ }^{187}$ Even if an international body collects the revenue and sends back an equivalent side payment to the national government, the side payment may not vitiate the effect of taxing the private polluters.

Another transnational assumption could, however, support

(3rd ed. 1993).

182. See id. at 293-95 (explaining that the real cost of a tax is the deadweight loss, any reduction in output that the tax triggers). A pollution tax may not have any deadweight loss to the degree it spurs substitution of inputs or increased efficiency.

183. See Wiener, Global Environmental Regulation, supra note 7, at 727-34.

184. See id. at 730 .

185. Id. at 763 .

186. See id.

187. See, e.g., Robert W. Hahn, Economic Prescriptions for Environmental Problems: How the Patient Followed the Doctor's Orders, 3 J. ECON. PERSP. 95, 104-07 (1989) (describing effluent taxes dedicated to funding environmental improvements); Richard B. Stewart, Economics, Environment, and the Limits of Legal Control, 9 HARV. ENVTL. L. REV. 1, 12 n.31 (1985) (noting that revenues from a pollution tax can subsidize pollution abatement). 
Wiener's analysis. A direct side payment to the payers of the tax would vitiate the tax's effect. But one could structure side payments without directing the side payment to polluters paying the tax. Indeed, Professor Wiener's reason for favoring side payments, developing countries' tendency to attach more priority to non-environmental issues, might support side payments to the state to allow it to address these competing priorities. ${ }^{188}$

Professor Wiener still has grounds to prefer international allowance trading over internationally mandated pollution taxes generally (rather than only under some transnational assumptions). He explains that countries may raise taxes on targeted pollutants, but undercut their effectiveness through reduced subsidies and taxes that otherwise apply to the polluters. ${ }^{189}$ His discussion of these points, however, does not include evaluation of potential remedies to these problems. By contrast, his discussion of trading evaluates some crucial problems and proposes some remedies, such as caps.

This imbalance probably reflects the intense academic interest the Kyoto Protocol has generated in thinking about trading. It is not immediately apparent that keeping track of nations' subsidies and energy taxes would pose more of an implementation challenge than keeping track of some of the trading games that this Article has discussed.

Indeed, an analysis of the transnational structure of trading versus taxes suggests quite the opposite. Since the potential games that could threaten the efficacy of taxes involve public subsidies and taxes, usually enacted by laws, they should be fairly easy to monitor and understand. By contrast, the potential games that could undermine the environmental performance of private-sector emissions trading require monitoring numerous private transactions and not just government measures. This might suggest that monitoring game playing, while difficult in both contexts, may prove easier in the tax context.

Legal process is important to instrument choice. But understanding: the relationship between participation and instrument choice fully requires a transnational, not just an international, perspective. Analysis of the participation cost of environmental taxes under voluntary assent must include express assumptions about where the money goes, meaning who precisely gets it and who pays it.

188. See Wiener, Global Environmental Regulation, supra note 7, at 778-79.

189. See id. at 785-87. 


\section{B. Comparing Trading and Performance Standards}

A transnational legal process analysis demonstrates that subsidizing developing country reductions through international allowance trading does not necessarily cost less than direct subsidy of performance standards in developing countries. A developed country has an incentive to pay the lowest possible abatement cost whether it claims credits for the purchased abatement (a subsidy embedded in allowance trading) or simply buys abatement outright from developing countries to supplement domestic reductions (subsidized performance standards). This would suggest that side payments cost the same whether used in conjunction with performance standards or allowance trading. ${ }^{190}$

Professor Wiener states that "fixed quantity targets do not attain the cost-effectiveness advantages of tradable allowances." ${ }^{191}$ But he does not explain why they do not, since after all, any side payment purchasing cheap reductions from abroad will realize cost savings relative to the price of making additional reductions at home regardless of instrument choice.

A transnational legal process analysis aids understanding of whether trading with embedded side payments enjoys a participation efficiency advantage over direct payment for environmental improvement. One can compare the participation efficiency of a "cap and pay" approach that involves international allowance trading to one that does not by analyzing the range of possible transnational transactions.

In theory, several transnational side payments are possible. Either the government or private parties of a developed country might pay the government or private parties of a developing country for reductions. Furthermore, in theory these payments could simply supplement reductions made at home (a performance standard or transnational pluralist approach) or secure credits in lieu of developed country reductions (international allowance trading). It is not clear that participation efficiency would vary with the choice between allowance trading and direct side payments. The purchase price of a reduction will not necessarily decrease just because the purchasing country plans to credit the reduction to its own account rather than simply count it as a supplement to the global effort.

Professor Wiener plausibly suggests that private parties'

190. See id. at 764 .

191. Id. at 764 . 
transactions will prove more cost-effective in practice than transactions directly involving government. ${ }^{192}$ In theory, one could use private party transactions with or without allowance trading. Debt for nature swaps, in which conservation organizations retire developing country debt in exchange for protection of important habitats, offers an example of a private party side payment without allowance trading. ${ }^{193} \mathrm{~A}$ developed country government could obligate private parties to directly purchase reductions abroad or it could impose a stricter standard upon the private parties for their own environmental performance, but authorize trading. However, one might doubt the feasibility of imposing a direct obligation upon a private party to purchase reductions abroad. The combination of direct private side payment's infeasibility and the posited cost-effectiveness advantage of private transactions might then lead to a costeffectiveness advantage for private sector allowance trading, rather than international allowance trading in general.

This analysis focuses upon only one element of Professor Wiener's participation efficiency function, the cost of the side payment. ${ }^{194}$ And it shows that a transnational legal process perspective reveals that equally cheap reductions are available with or without trading. However, it does show that private party trading may offer a cost-effectiveness advantage over public trading insofar as private parties find available cheap reductions better than governments do and direct private payment without credits is infeasible.

But a more general problem lurks behind Professor Wiener's claim that participation efficiency creates a general costeffectiveness advantage that justifies a strong presumption in favor of allowance trading. ${ }^{195}$ Professor Wiener does not explain how one separates participation efficiency from the generic conventional analysis of instrument choice. He explains that the concept of "participation efficiency" refers to "attracting participation at least cost." ${ }^{196} \mathrm{He}$ suggests that this concept is distinct from "cost-effectiveness" and other elements of the "standard analysis." 197 But treating the cost-effectiveness

192. See id. at 766-67.

193. See id. at 713 n. 149 .

194. See id. at 748 .

195. See id. at 764 (the failure of fixed quantity targets to attain "the costeffectiveness advantages of allowance trading . . . means higher global costs . . . and ... lower incentives for cooperative winners to cooperate").

196. Id. at 742 .

197. Wiener states that participation efficiency "becomes as important as cost- 
advantages of allowance trading generally as a component of participation efficiency blurs the concept of participation efficiency. Analysis should focus on how the increment in costeffectiveness that comes with participation varies with instrument choice.

When Professor Wiener describes allowance trading's cost efficiency, he cites studies showing cost savings from fifty to seventy percent. ${ }^{198} \mathrm{He}$ notes that allowance trading limited to industrialized countries yields cost savings from forty to fifty percent. ${ }^{199}$ This would suggest that the incremental costeffectiveness associated with securing developing country participation would be between zero and thirty percent. Yet, he writes that "reducing marginal abatement costs through wider participation (especially by developing countries) is also a prerequisite to obtaining the estimated fifty to seventy percent cost-effectiveness gains of global incentive instruments." ${ }^{200}$ This statement obscures the point that an analysis of participation efficiency should count the incremental cost-effectiveness associated with bribing new participants and exclude the costeffectiveness advantages already obtained without their participation.

Since one can cheaply pay for abatement under a cap with or without allowance trading, one wonders why Professor Wiener is so convinced that allowance trading offers the world's only hope of inducing developing country "participation" in global environmental efforts. ${ }^{201}$ Perhaps the difficulty lies in his failure to define participation.

One might define participation as being the host country for developed country abatement efforts under allowance trading. Such a definition tautologically favors allowance trading. This definition would suggest that participation comes costlessly, since one could add participants without adding environmental performance. Even fairly sophisticated scholars and policymakers sometimes write as if allowance trading directly adds environmental benefits to an international environmental

effectiveness . . . and the other" elements of the "standard analysis." Id. at 742. This statement suggests that participation efficiency captures something distinct from the "standard analysis."

198. See id. at 717.

199. See id.

200. Id. at 748 .

201. Id. at 751 (suggesting that proponents of competing instruments are "implicitly willing to" leave "major countries out of the regime"). 
regime. ${ }^{202}$ In general, it does not.

For example, assume that a developed country obligates itself to reduce emissions by 100 tons. Without trading it reduces its domestic emissions by 100 tons. International trading allows it to purchase some or all of its reductions abroad in lieu of full domestic compliance. This purchase adds nothing to global environmental progress. It constitutes a cost-effective way of relocating reductions that would otherwise occur.

Professor Wiener, however, does not make the mistake of treating trading as automatically adding emission reductions to the global effort. Rather, he pays for his supplemental side payment under allowance trading by increasing the stringency of developed country obligations. ${ }^{203}$

One might imagine that a trading mechanism will magically induce developing countries to accept a cap, while a side payment from a government that does not get credit would not. Professor Wiener proposes that developing countries assume a cap exceeding current emissions, a cap with "headroom."204 Using side payments to purchase agreements to a cap with headroom would be difficult under any instrument. Such a cap creates an inchoate future obligation that poses significant valuation problems. A country assuming a cap with headroom effectively agrees to limit activities causing environmental harm in the future once the allowed emissions, for example, rise to a given level. It will prove difficult to predict the rate of growth of the underlying activities, the activities' pollution rates, and the future cost of abatement. ${ }^{205}$ The obligation to assume a cap represents an additional environmental commitment beyond current abatement obligations. So explanations of how instruments compare in purchasing current abatement do not help explain whether a given instrument might facilitate agreement to a cap with headroom.

Moreover, equity may not favor payment to assume a cap. Developing countries have accepted some responsibility to abate their own emissions in the future, ${ }^{206}$ and they should, especially

202. See Driesen, Free Lunch, supra note 5, at 83 n.414.

203. See Wiener, Global Environmental Regulation, supra note 7, at 765.

204. Id.

205. See generally David M. Driesen. Should Congress Direct the EPA to Allow Serious Harms to Public Health to Continue?: Cost-Benefit Tests and NAAGS Under the Clean Air Act, 11 TULANE ENVTL. L.J. 217, 228-29 (1998) (discussing the difficulty of estimating future abatement costs).

206. See, e.g., Driesen, Free Lunch, supra note 5, at 11-12 lexplaining how Montreal Protocol and Climate Change Treaty share an expectation that developing countries will eventually have control obligations). 
after their own development advances enough to generate significant emissions. ${ }^{207}$ Developed countries may question the equity of allowing countries wealthy enough to generate significant emissions to assume no obligation. ${ }^{208}$

In short, there is no reason to assume that allowance trading makes it easier to get agreement to caps. Nor does allowance trading necessarily make side payments cheaper. A transnational perspective, however, clarifies a modest participation cost-effectiveness advantage for private sector trading over publicly subsidized performance standards. But it also shows that international allowance trading may hinder effective participation by generating more need for decisions under voluntary assent.

\section{The Missing Link: Participation Cost and Domestic Legal Process}

The conventional instrument choice account claims that allowance trading somehow overcomes the problem of slovenly implementation of pollution control programs. ${ }^{209}$ I have argued elsewhere that the reasoning supporting this view is not sound..$^{210}$ The participation cost concept, however, might provide the missing link between the general cost-effectiveness advantages associated with trading, and the claim that trading will overcome the lethargy of traditional environmental regulation.

From a transnational legal process perspective, a domestic participation cost advantage would be relevant to international instrument choice. ${ }^{211}$ After all, nations' domestic laws will implement international obligations. Perhaps a participation cost concept can help predict which instruments will best encourage developed countries to make the side payments necessary to secure developing country participation in international

207. See Paul G. Harris, Common but Differentiated Responsibility: The Kyoto Protocol and United States Policy, 7 N.Y.U. ENvTL. L.J. 27, 37 (1999) (noting correlation between greenhouse gas emissions and GNP); $c f$. Climate Change: Economic Growth Up, Carbon Emissions Down in 1998, Worldwatch Institute Says, 30 Env't Rep. (BNA) 644 (July 30, 1999).

208. See generally Driesen, Free Lunch, supra note 5, at 19-21 lexplaining that developing countries' failure to commit to making reductions explains the United States' failure to ratify the Kyoto Protocol).

209. See Ackerman \& Stewart, supra note 6, at 179-85.

210. See Driesen, Emissions Trading, supra note 24, at 327-31.

211 . Professor Wiener states that his call to take the legal framework into account has implications for domestic environmental policy as well. See, e.g., Wiener, Global Environmental Regulation, supra note 7, at 754. 


\section{agreements.}

Analysis of the cost of taxes to polluters may help explain some polluters' resistance to national pollution taxes better than it explains how an international decisional rule changes national participation costs. ${ }^{212}$ As long as the government gives away allowances, allowance trading costs polluters less than pollution taxes. ${ }^{213}$

For example, the United States has allowance trading programs but no serious environmental taxation. ${ }^{214}$ Perhaps a participation cost concept could help explain how polluters' preference for allowance trading might influence the United State's policy choice to neglect pollution taxes, which may be more economically sound for the society as a whole than allowance trading. ${ }^{215}$ To do this, the concept must include not just legal and economic, but also political analysis. ${ }^{216}$

Public choice theory would predict that organized special interests might influence political decisions regarding instrument choice. ${ }^{217}$ This might help explain why we do not have environmental taxes. ${ }^{218}$

212. See BAUMOL \& OATES, supra note 101 , at 52-53 (explaining that polluters face a tax bill for residual emissions); James M. Buchanan \& Gordon Tullock, Polluters' Profits and Political Response: Direct Control Versus Taxes, 65 AM. ECON. REV. 139, 141-42 (1975) (explaining why polluters may prefer a regulation to a tax). See generally Dawn Erlandson, The BTU Tax Experience: What Happened and Why It Happened, 12 PACE ENVTL. L. Rev. 173 (1994) (discussing President Clinton's unsuccessful effort to secure a pollution related tax); Frank Muller \& J. Andrew Hoerner, Greening State Energy Taxes: Carbon Taxes for Revenue and the Environment, 12 PACE ENVTL. L. REV. 5 (1994).

213. See Wiener, Global Environmental Regulation, supra note 7 , at 710 .

214. See Hahn, supra note 187 , at 107 (noting that most pollution charges in effect are not large enough to greatly influence polluters' behavior).

215. See Buchanan \& Tullock, supra note 212 , at 142 (explaining how pollution taxes could benefit society as a whole).

216. See generally Nathaniel $O$. Keohane et al., The Choice of Regulatory Instruments in Environmental Policy, 22 HARV. ENVTL. L. REV. 313 (1998) (discussing how an "equilibrium model" might help explain national instrument choice and reviewing some of the other types of explanatory frameworks).

217. See generally KENNETH J. ARROW, SOCIAL CHOICE AND INDIVIdual VAlues (3rd ed. 1966); James M. BuChanan \& GoRdon TUllock, THE Calculus of CONSENT: LOGICAL FOUNDATIONS OF CONSTITUTIONAL DEMOCRACY (1962); MORRIS P. FIORINA, CONGRESS: KEYSTONE OF THE WASHINGTON ESTABLISHMENT (2d ed. 1979); JERRY L. Mashaw, Greed, Chaos, and Governance: Using Public Cholce to Improve Public LAW (1997); DAVID R. MAYHEW, CONGRESS: THE ELECTORAL CONNECTION (1974); DENNIS C. Mueller, Public Choice (1979); William H. Riker, liberalism Against Populism: A CONFRONTATION BETWEEN THE THEORY OF DEMOCRACY AND THE THEORY OF SOCIAL CHOICE (1982); Amartya K. Sen, Collective Choice and Soclal Welfare (1970); Daniel A. Farber \& Philip P. Frickey. The Jurisprudence of Public Choice, 65 TEx. L. REV. 873 (1987); Mark Kelman, On Democracy-Bashing: A Skeptical Look at the Theoretical and 'Empirical' Practice of the Public Choice Moverment, 74 VA. L. REv. 199 (1988).

218. See generally Buchanan \& Tullock, supra note 212 , at 141-42. 
If one assumes that polluters have political influence upon instrument choice in the United States, even under a majority voting rule, then polluter preferences may trump sound societal economics for political reasons, at least in this country. One might use comparative political analysis to evaluate whether polluters have strong influence over instrument choice in other countries as well. ${ }^{219}$ One might ask, for example, why other countries have higher energy taxes than the United States. ${ }^{220}$

Polluters have influence over regulatory decisions as well. Professor McGarity has argued that regulated industries have often paralyzed rulemaking by exploiting opportunities to comment exhaustively on rulemaking and securing judicial remands of disliked rules. ${ }^{221} \mathrm{He}$ refers to the "ossification" of the rulemaking process. ${ }^{22}$ If Professor McGarity's analysis captures important features of domestic legal process, and many informed observers think it does, ${ }^{223}$ then regulators may want polluter assent to regulation, even when the formal legal rules allow agencies to impose regulations upon non-consenting polluters.

Since polluters enjoy reduced cost under allowance trading, perhaps adoption of an allowance trading program may make it easier to secure polluters' cooperation in accepting regulation. If regulated industries become convinced that allowance trading will reduce their cost, maybe they will "participate," in the sense of accepting limits, rather than resisting limits through litigation

219. See, e.g., SuUR Kasa, Soclal and Polttical Barriers to Green TAX Reform: THE CASE OF $\mathrm{CO}_{2}$ TAXES IN NORWAY, available at <www.cicero.uio.no> (seeking to explain why Norway's taxes on carbon dioxide emissions do not apply to certain energy intensive industries).

220. See International Energy Agency, Monthly Price Statistics, tbl. 1 (July 12, 1999) <http://www.iea.org/pub.htm>.

221. See Thomas McGarity, Some Thoughts on "Deossifying" the Rulemaking Process, 41 DUKE L.J. 1385, 1397. 1400-03 (1992). Professor McGarity cites these factors as working together with other rigidifying factors. See id. at 1403-36.

222. See id.; see also Thomas $O$. McGarity, The Courts and the Ossification of Rulemaking: A Response to Professor Setdenfeld, 75 TEx. L. REV. 525 (1997).

223. The term ossification apparently originated in a speech Donald Elliott gave when he was general counsel of the Environmental Protection Agency. Symposium Remarks, Assessing the Environmental Protection Agency After Twenty Years: Law, Politics, and Economics (Duke University School of Law, Nov. 15, 1990). A number of others have agreed with Professor McGarity's diagnosis of the problem Elliott mentioned. See, e.g., Richard J. Pierce Jr., The Fiftieth Anniversary of the Administrative Procedure Act: Rulemaking and the Administrative Procedure Act, 32 TULSA L.J. 185 (1996); Peter L. Strauss, The Rulemaking Continuum, 41 DuKE L.J. 1463 (1992); $c f$. Patricia M. Wald, Judicial Review in Midpassage: The Uneasy Partnership Between Courts and Agencies Plays On, 32 TuLSA L.J. 221 (1996); Patricia M. Wald. Thirty Years of Administrative Law in the D.C. Circuit, 11 PIKE \& FISCHER's ADLAW BULLETIN NO. 13, at 1, 4-5 (1997) (arguing that the ossification theory rests more upon anecdote than strong empirical evidence). 
and obstruction.

This logic may appeal to government agencies seeking to overcome industry resistance to regulation. This logic, however, contains few limits. Application of allowance trading to problems that it cannot address well, for example, poorly monitored pollution, will overcome industry resistance more effectively than appropriate application of allowance trading. ${ }^{24}$ Indeed, one might buy more participation through reduced stringency regardless of the choice of regulatory instrument.

Perhaps this analysis should not apply to the domestic legal context, where the regulator has sufficient legal authority to compel compliance. But in light of the potential utility of polluter assent, serious thinking about its potential as well as the need for limits appears wiser.

No economic reason exists for a polluter to agree to an allowance trading program absent a credible government ability to impose a traditional regulatory program. ${ }^{225}$ Allowance trading only reduces costs; it does not eliminate them. If, however, the government clearly remains willing to impose a non-trading program upon the polluter, then the polluter has an incentive to agree to a trading program in order to seize the cost savings. ${ }^{226}$

This model suggests a strategy for good government. Government can demand polluter assent to good monitoring and game proof rules as part of an agreement under which the government authorizes allowance trading.

The possibility that allowance trading may lower domestic participation costs without harming environmental quality invites a question about international allowance trading: Does private international allowance trading make the side payments needed to attract broad international participation easier than competing mechanisms? Professor Wiener advocates an international allowance trading system where developed countries assume more stringent obligations. The increased stringency induces regulated polluters to make private side payments; the polluters purchase credits in lieu of assuming the

224. See Driesen, Emissions Trading, supra note 24, at 321-22.

225. Professors Ackerman and Stewart have argued that auctioning of pollution permits would reduce "the opportunity and incentive of polluters to use the legal system for delay and obstruction." Ackerman \& Stewart, supra note 6, at 182-83. I have argued elsewhere that their view is not correct. See Drlesen, Emissions Trading. supra note 24, at 327-32. Even if trading reduced opportunities for obstruction, it would not eliminate them.

226. Negotiations with polluters already play a role in administrative law. See Daniel A. Farber, Environmental Federalism in a Global Economy, 83 VA. L. REv. 1283, 1315 n.161 (1997). 
incremental cost of making more reductions at home. ${ }^{227}$ Wiener contrasts this private trading system to other systems where government revenues, raised through taxation, finance the side payments directly. ${ }^{228}$ Therefore, one must compare the domestic "participation efficiency" of more stringent emission standards under trading to direct increased government spending as a financing mechanism in order to determine whether allowance trading makes side payments easier. ${ }^{229}$

Professor Wiener sidesteps this issue of whether one instrument offers a financing mechanism more easily enacted than another. He states that foreign aid (government spending) "may be subject to more domestic political opposition than trade." ${ }^{230}$ He contrasts outright transfers (government spending) with "numerous small transfers from private" developed country sources to "lower-cost abaters in developing countries (private trading)."231 This analysis ignores the hard political issue of gaining acceptance for the increased stringency to pay for the side payment under private international allowance trading.

It would require a major work of comparative law and political science to answer the question of whether imposing a more stringent obligation upon polluters to generate indirect side payments would be more "participation efficient" than imposing an increased tax burden on everybody for decreases in other budget expenditures) to fund a direct side payment. But some pieces of this large and complicated picture appear especially relevant to the theory of instrument choice.

First, polluters will tend to prefer taxpayer financing to an obligation that forces them, rather than the general public, to pick up the tab. In a polity where polluters have great influence this may make direct side payments more attractive. Second, the tax obligation may appear cheaper than the increased stringency of control obligations at the time of enactment. Taxpayers would

227. See Wiener, Global Environmental Regulation, supra note 7, at 765.

228. See id. at 765-66.

229. Professor Wiener mentions the possibility of funding performance standards directly with aid without claiming a credit. See id. at 764 . But he ignores this possibility when he analyzes the difference between direct government finance and private party finance. See id. at 764-67. Instead, he focuses upon two variations of a trading program, one in which the government pays for reductions in order to reduce domestic aggregate obligations and another, where private sources purchase reductions in lieu of making them themselves. See id. But government purchase of performance without credits uses the same funding mechanism as allowance trading by governments. So the same analysis applies.

230. Wiener, Global Environmental Regulation, supra note 7, at 766.

231. Id. 
view themselves as funding reductions at cheap developing country prices. Polluters, however, might base their arguments against the imposition of environmental obligations on their own relatively high marginal control costs.

Governments could justify imposing a sufficient pollution control obligation to generate side payments comparable to those a government expenditure might provide only if it rejects calls to base its decisions upon domestic polluters' own abatement cost. The government would have to take the lower cost of foreign abatement into account when setting the stringency of pollution control limits. Otherwise, the developed countries' high abatement costs would tend to constrain the incremental stringency of the limits that should generate side payments.

Governments can reasonably demand increased stringency in return for agreeing to allowance trading generally. Cost considerations typically constrain decisions about the stringency of pollution standards. ${ }^{232}$ If allowance trading offers large cost savings to polluters, then governments can use some of the cost savings to purchase additional environmental protection. Governments can increase the stringency of the standards underlying an allowance trading program, while leaving enough cost savings to sources to motivate trading. ${ }^{233}$

Absent a willingness and ability to take the lower marginal abatement costs of trading into account when setting standards to generate side payments, aid enjoys a significant advantage over trade in "participation efficiency." It follows that subsidized performance standards and taxes (both using aid rather than trade to subsidize reductions) would enjoy a domestic participation cost advantage over private allowance trading when the government bases standards upon the marginal abatement cost of domestic polluters.

Third, even if the government took the cost savings into account, the polluter's preference for a direct governmental side payment over an increased obligation for itself still may influence policymakers. A public choice theory might predict that publicly financed obligations would be easier to implement because they do not burden narrow and well-organized groups.

Professor Wiener imagines that the government need not collect "data on sources' abatement costs" when it uses

233. See Driesen, Emissions Trading, supra note 24, at 331-32. 
allowance trading. ${ }^{234}$ If this were correct, then allowance trading would enjoy a much greater participation efficiency advantage than even Professor Wiener claims. Presumably, if states did not need data on control costs, this would imply that control costs did not matter to them under allowance trading.

In reality, of course, allowance trading does have control costs and countries may consider these costs in deciding whether and how to participate in an international agreement when allowance trading is proposed. Wiener argues correctly that "[elvery regulatory instrument," including allowance trading, "requires an initial decision on how ... regulatory constraint[s]. . . will be assigned across regulated entities." ${ }^{235}$ To the extent that nations consider costs when deciding whether to participate in an international agreement and how to design their compliance program, they will need information about pollution sources' control costs. ${ }^{236}$ Any cost-effectiveness advantage from allowance trading will have no effect upon participation decisions unless government takes into account the cost savings available from trading when making participation decisions. ${ }^{237}$

This need to take trading cost savings into account implies that government officials must approach instrument choice agnostically, rather than presumptively favoring allowance trading. ${ }^{238}$ Religious devotion to trading will tend to foster trading programs without the added stringency necessary to add environmental benefits from wider participation. Government should use allowance trading as a carrot to improve international environmental protection and rule out trading where it cannot work. ${ }^{239}$ This requires a government that evaluates instrument choice in conjunction with design decisions in a concrete context, not as an a priori presumption.

This approach, rather than a religious devotion to allowance trading in general, might provide the missing link between the cost-effectiveness advantages of trading and some concrete advantage in securing effective participation in global

234. Wiener, Global Environmental Regulation, supra note 7, at 775.

235. Id. at 776 .

236. See Driesen, Emissions Trading, supra note 24, at 327-29 (explaining that regulators may consider cost in setting limits on allocation of tradable allowance). But cf. Heinzerling, supra note 37, at $\mathbf{3 2 5}$ (arguing that control cost information on acid rain was gathered, but not considered, in establishing the acid rain program).

237. See Driesen, Emissions Trading, supra note 24, at 331-32.

238. See, e.g., id. (developing a functional theory of economic incentives as an alternative to "quasi-religious" faith in programs labeled as economic incentives).

239. See Wiener, Global Environmental Regulation, supra note 7, at 681-82 (recognizing that good instrument choice depends upon context). 
agreements. Scholars need to analyze trading in conjunction with transnational legal process.

\section{CONCLUSION}

This discussion offers some general lessons about putting the law back into law and economics. Economists often model instruments' effects by choosing rigidly fixed assumptions and reasoning from them. Academic lawyers have an important role to play in clarifying the legal process assumptions that should inform the economic analysis of problems implicating the legal system. An understanding of transnational legal process must inform analysis of instruments to improve the global environment.

Careful legal analysis of implementation constraints and legal process might advance the instrument choice debate. A realistic sense of the challenges various instruments pose for legal processes and government institutions should inform instrument choice. ${ }^{240}$

Law and economics perspectives may not be sufficient to understand something as complex as national participation decisions. We may need political science as well. ${ }^{241}$ Indeed, a transnational approach makes comparative legal and political analysis especially salient.

Any theory of global instrument choice must take countries' perceptions of the comparative equity of instruments seriously. International allowance trading may discourage participation in international agreements because developing countries often find it inequitable.

Because international allowance trading relies upon international transactions in implementation, it will generate a need for voluntary assent to more international rules than one would need under transnational pluralism. It increases the chances of a failure to reach agreement and may encourage defections or implementation failures.

A transnational legal process analysis casts doubt on any presumption that international allowance trading generally enjoys greater "participation efficiency" than pollution taxes or traditional regulation. It suggests some significant advantages for

240. See generally Howard Latin, Ideal Versus Real Regulatory Efficiency: Implementation of Uniform Standards and "Fine Tuning" Regulatory Reforms, 37 STAN. L. REV. 1267, 1270-1271 (1985).

241. See Hahn, supra note 187 , at 111 (discussing need for comparative study of political institutions and interest groups to understand comparative instrument choice). 
a transnational pluralist approach, which allows for domestic allowance trading without the need for extraordinarily demanding international coordination.

An instrument's attractiveness to national governments and their polluters does matter to debates about global instrument choice. But predictions about which instruments will best foster participation must include analysis of the politics involved and design considerations.

Although this Article focuses on how transnational legal process might influence participation, it offers an additional and simple lesson about international trading. Because international trading contemplates international transactions, it will complicate compliance and enforcement. Scholars should evaluate how much weight to give this defect in a transnational legal context and in the particular contexts of various global environmental problems. 